\title{
KREATÍV FOGLALKOZÁSOK ÉS REGIONÁLIS TUDÁSBÁZIS: FOGALMAK, FOLYAMATOK ÉS TERÜLETI ÖSSZEFÜGGÉSEK
}

\author{
(Creative Occupations and Regional Knowledge Base: \\ Concepts, Trends and Territorial Correspondences)
}

\section{LENGYEL BALÁZS - SÁGVÁRI BENCE}

\begin{abstract}
Kulcsszavak:
innovációs rendszer tudásbázis kreatív munkaerō regionálisfejlödés 3 Tmodell

A tudásalapú gazdaság területi vizsgálataiban egyre nagyobb jelentôséget kap az a kérdés, hogy a munkaeró képzettségi szintje vagy a foglalkozások jellege eredményezi-e a régiók kiemelkedését. Tanulmányunkban bemutatjuk a regionális innovációs rendszerek tudásbázisának foglalkozási oldalú megközelítését, és sajât kategóriákat vezetünk be a kreatív munkaerō és tudásbázis számbavételére.

Ezekre a kategóriákra alapozva tekintjük át a kreativ munkaerỏ és a regionális tudásbázis volumenêt 1996, 2001 és 2005 években. Ezt követöen egy Svédországban tesztelt regressziós modell alapján a kistérségek fejlettségét a kreatîv munkaerö volumenével, gazdaságának technológiai szinvonalával, tolerancia-szintjével, az egyetemi képzés volumenével és az igénybe vehetö szolgáltatások sokszinüségével magyarázzuk. A skandináv modellt tovább fejlesztjuik, és az egyetemi képzések és a foglalkozási tudásbázis terïleti összefüggéseit kutatjuk.

Eredményeink szerint a tudás teremtésében aktív kreatív foglalkozások magyarázzák leginkább a regionális fejlettséget, ezt a tudást alkalmazó foglalkozások követik, mig a vezetỏ pozíciók foglalkozásai bírnak a leggyengébb magyarázóerōvel. Magyarországon a felsőfokú végzettségü munkaerö eredményesebben magyarázza a régiók fejlettségi különbségeit, mint a kreatív foglalkoztatottak. Az egyetemi képzés hatása a lokális tudásbázisra erósebb a természet-, élet-és müszaki tudományok esetében, mint a jog-és társadalomtudományok terén. Kisérleteink eredményei azt jelzik, hogy a globalizáció elsó számú nyertese a fõváros és agglomerációja, a külkapcsolatok helyi müködtetéséhez szükséges gazdasági-, jogi-és egyéb târsadalomtudományi tudás egyre nagyobb mértékben koncentrálódik Budapesten.
\end{abstract}

\section{Bevezetés}

A gazdaság tudásalapú szervezỏdése nagyban összefügg azzal az átmenettel, melyben a nagyüzemi termelés helyébe a rugalmas, személyre szabott termelési módok kerüiltek, s a szolgáltatások szerepe megnótt (Lengyel I. 2003; Lengyel I.Rechnitzer 2004; Papanek 2006). Az új típusú szolgáltatásokat felsőfokú végzettséggel rendelkező munkavállalók végzik, akik a városok egyetemein szerzik meg képzettségüket (Rechnitzer-Csizmadia-Grosz 2004; Varga 2004). Az egyes térségek felemelkedésének kulcseleme, hogy milyen a foglalkoztatottak képzettségi színvonala (Glaeser et al. 1992), a képzett munkaerỏ milyen foglalkozásokban 
kamatoztatja tudását, s kreativitását tudja-e hasznosítani, döntéseit mennyire önállóan hozza meg (Cooke-Schwartz 2007).

A kreatív munkavégzést vizsgáló tanulmányok az önkifejezésen, önálló döntéshozatalon alapuló foglalkozások értékteremtésére fókuszálnak (Rimler 2000). Ugyanakkor a gazdaságföldrajzi szemlélet egyik központi kérdése, hogy a kreatív foglalkoztatottak milyen mértékben járulnak hozzá egy város vagy régió gazdasági teljesítményéhez (Florida 2002a). A kreatív munka során jön létre az új tudás, amely a gazdasági cseremechanizmusok során hasznosul. Ha a kreatív munka írásban nehezen kommunikálható, hallgatólagos tudáson alapul (Lengyel B. 2004; AsheimCoenen 2006), akkor a gazdaság tudásalapú szerveződését inkább lokális módon vezérli; ez a tudás a helyi környezetre vonatkozik. Amennyiben a kreatív munka könnyen leírható, explicit tudáson alapul, és szigorú szabályok korlátozzák a létrehozását, úgy a tudásalapú szerveződés globális szinten megy végbe, ez a tudás megérthetö a Föld másik felén is.

A területi vizsgálat módszeréül Richard Florida és szerzötársainak (2008) modelljét választottunk. Ennek alapján a hazai kistérségek fejlettségét a kreatív munkaerö volumenével, gazdaságának technológiai színvonalával, tolerancia-szintjével, az egyetemi képzés volumenével és az igénybe vehető szolgáltatások sokszínủségével magyarázzuk. A modell együtthatóit a később részletesen bemutatott regressziós egyenletekből kapjuk. A modellt tovább fejlesztjük, megkülönböztetjük benne a globális szinten hasznosulni képes természet- és élettudományi, illetve mérnöki tudásbázist, a lokális környezetbe ágyazódó gazdasági-, jogi- és társadalmi tudásbázist, valamint a müvészeti és kulturális munkavégzéshez kapcsolódó tudásbázist. E kategóriák alapján kutatjuk az egyetemi képzések és a foglalkozási tudásbázis területi összefüggéseit.

Az első fejezetben áttekintjük a kreatív osztály, kreatív munkavégzés és tudásbázis nemzetközi irodalomban használt fogalmait. Ugyanitt ismerhetö meg a magyar vizsgálatban használt foglalkozási kategóriákra épülö tudásbázis fogalomrendszerünk is. Ezt követően a második fejezetben bemutatjuk a kreatív munkavégzés 1996 és 2005 közötti alakulását, megyei adatokra támaszkodva. A területi vizsgálat 3 T modelljét és annak hazai alkalmazhatóságát a harmadik fejezetben tekintjük át. A negyedik fejezetben az útmodellben használt indikátorokat, a modell dekompozícióját és az eredményeket mutatjuk be. Az ötödik, záró fejezet a kutatás konklúzióját és a további kutatási irányokat tartalmazza.

\section{A kreativ munkavégzés területi fogalmai és kategóriái}

A kreatív munkavégzés és területi fejlödés összefüggéseit a kreatív osztály és a regionális innovációs rendszerek tudásbázisa segítségével közelítjük meg. Ebben a fejezetben a két irányzat föbb fogalmait vesszük sorra. Ezt követően az irányzatok ötvözésének céljával részletesen bemutatjuk a foglalkozások újszerủ tipizálására tett kísérletünket. 


\section{Kreatív munka, kreatív foglalkozások és kreatív osztály}

A kreativitás fogalmának közgazdasági gyökerei egészen Schumpeterig (1961) nyúlnak vissza. A kreatív rombolás (creative destruction) azt a folyamatot jelenti, amikor egy már létezó termék, munkavégzési forma, szervezeti vagy intézményi berendezkedés kiszorul az új megjelenésével; sőt, akár egy új termék egészen más utakat nyithat a verseny számára, így rombolva a korábbi berendezkedés struktúráit. A kreatív munkavégzés tehát elsősorban az innovációhoz, az új értékek, új minőségek, új tudás létrehozásához kötődik.

A kreatív munkaeró területi fejlödésre való hatását legföképpen az urbanizációs elönyökre vezetik vissza (Jacobs 1969). A kreatív iparágak jellemzően nagyvárosokban jelentek meg, ahol a tudásáramlás és tudás-túlcsordulás a személyközi hálózatok sủrúsége miatt könnyen megvalósul iparágak között is. A nagyvárosi sokszínúség a közege a kreatív munkavégzésnek, hiszen ezekben a másoktól való megküilönböztetés az értékteremtés fö jellemzője ( $S$ cott 2007).

Florida (2002a) szerint a tudásalapú gazdaság elötérbe kerülésével a munkakörullmények megváltoztak, a hierarchikus alá-fölé rendeltséget a lapos szervezetek, a formális szabályokat a puha-ellenőrzés (soft-control), az önmenedzselés, egymás kölcsönös elismerése és motiválása váltja fel. A kreatív foglalkozásokban a munkavégzés saját ritmus alapján történik, a fó jellemzői pedig a tanulás és fejlődés, a munka tartalmának szabad alakítása, az identitás kifejezése. Ezen változások egy új „kreatív osztály” felemelkedését eredményezték. Ebbe az új osztályba tartoznak a tudományok mủvelői, a mérnökök, az építészek, a dizájnerek, az oktatás, a múvészetek és a szórakoztatóipar területén foglalkoztatottak. Szintén ide sorolhatjuk bár nem a „,belső körbe” tartoznak - az üzleti élet, a pénzügyek, a jog és az egészségügy területén dolgozó képzett szakembereket is. Florida arra mutat rá, hogy az amerikai metropolita régiók fejlődése elsősorban a kreatív osztály jelenlététől, nem pedig a munkaerő képzettségétöl függ. Ebben a tanulmányban a kreatív munkának azt a tevékenységet tekintjük, amely felsófokú végzettséget igénylố foglalkozásokban valósul meg, viszonylag magas önálló döntéshozatalt és felelősségi kört követel, illetve valamilyen új minőség, új tudás teremtésére irányul.

\section{A regionális innovációs rendszerek tudásbázisa}

A tudásteremtés, a gazdasági cserekapcsolatok és a lokalitás közötti összefüggéseket az is meghatározza, hogy milyen típusú tudás jön létre. Asheim az egyetemek és a vállalkozások közös tudásteremtése szempontjából megkủilönbözteti az analitikus, szintetikus és szimbolikus tudást (Asheim-Isaksen 2002; Asheim-Gertler 2005; Asheim-Coenen 2006), ezekre épül az innovációs rendszerek tudásbázisa. A tudásalapú gazdaság területi dimenziójában a három tudásfajta eltérő szervezőerôvel bír:

- A szintetikus tudás a már meglévó ismeretek újszerü kombinációját, gyakorlatias tevékenységek elsajátítását jelenti; főleg alkalmazott kutatás (műszaki tudományok), kísérleti fejlesztés, induktív eljárások eredménye. A szintetikus 
Lengyel Balázs - Ságvári Bence : Kreatív foglalkozások és regionális tudásbázis:

Fogalmak, folyamatok és területi összefüggések. - Tér és Társadalom 23. évf. 2009/4. 1-26. p.

$4 \quad$ Lengyel Balázs - Ságvári Bence

TÉT XXIII. évf. 2009 - 4

tudás hallgatólagos jellege miatt fontos, hogy a gazdasági szereplök között kölcsönös megértés alakuljon ki, amit a fizikai közelség és gyakori személyes érintkezések nagymértékben elösegítenek. A szintetikus tudást használó vállalatok lokális iparági körzetekben szervezödnek, egymás közelségéből előnyt kovácsolnak a globális piacon.

- Az analitikus tudás formális modellek, tudományos elvek, racionális eljárások segítségével jön létre, föleg az alapkutatás (természettudományok) projektjei révén. A tudományos munka ugyanazokat a szabályokat követeli meg a világ minden pontján. A racionális és szigorú szabályokkal korlátozott analitikus tudásteremtés globális szinten szervezödik, hiszen jellegéböl fakadóan nagy távolságokba is könnyen transzferálható.

- A szimbolikus tudás nem a tudományos tudásteremtéshez kötődik, sokkal inkább a múvészi alkotáshoz, s így az ún. kreatív iparágakhoz. A szimbolikus tudásteremtés termékei (film, zenei album, színházi előadás stb.) legtöbbször olyan projektek során jönnek létre, ahol hasonló mentalitású emberek nagyon intenzíven dolgoznak együtt. Ezek a tudáselemek leginkább az alkalmazás során (learning-by-doing) sajátíthatók el. A szimbolikus tudásteremtés így döntően lokális módon szerveződik, a teremtett tudás nagy része lokális szinten is hasznosul, ugyanakkor a domináns kultúra termékei a globális piacon versenyeznek egymással.

A fenti szerzők esettanulmányok segítségével arra világítanak rá, hogy az egyetemek a szintetikus tudásbázis terén nagyobb hatást gyakorolnak a lokális innovációs rendszerre, mint az analitikus tudásbázis terén. Egy vállalat szintetikus, mérnöki tevékenysége ugyanis magasabb szinten hasznosítja egy térség hallgatólagos tudását (helyi kultúra, gyakorlati tapasztalatok), mint a természettudósok szabályozott tudásteremtése. Ugyanakkor nem található a szakirodalomban az állítások számszerüsített bizonyítása, amire jelen tanulmányunkban kísérletet teszünk. Ehhez azonban le kell szűkítenünk a vizsgálat tárgyát a foglalkozási kategóriák és az egyetemi képzés lokális kapcsolatára, amit a következőkben mutatunk be.

\section{Tudásbázis: kreatív foglalkozások és egyetemi képzés}

A kreatív osztályt - Florida kategóriáit továbbontva - három alosztályra osztottuk: kreatív irányítókra, a kreatív magra és a kreatív szakemberekre. A hármas tagolással új szempontokat kívántunk bevezetni a kreatív vizsgálatokba. Kísérletünkkel arra kívánjuk felhívni a figyelmet, hogy a hozzáadott érték teremtése lényegesen különbözik például a vezető pozíciókat betöltő foglalkozások és a tudományos-, müszaki-, mủvészi tevékenység között. Florida (2002a) ugyanakkor megelégedett azzal, hogy a kreatív osztályt szuperkreatívokra (ami nálunk a kreatív mag) és kreatív szakemberekre bontsa, az eddigi hazai vizsgálatok pedig vagy nem bontották részekre a kreatív osztályt, vagy együtt kezelték a vezetô beosztású és a valóban kreatív munkát végző kreatív munkaerőt. 
Lengyel Balázs - Ságvári Bence : Kreatív foglalkozások és regionális tudásbázis:

Fogalmak, folyamatok és területi összefüggések. - Tér és Társadalom 23. évf. 2009/4. 1-26. p.

TÉT XXIII. évf. 2009 @ 4

Kreativ foglalkozások és ...

5

\section{TÁBLÁZAT \\ A kreativ osztály felépitése \\ (Structure of the Creative Class)}

\begin{tabular}{|c|c|c|c|}
\hline $\begin{array}{l}\text { Kreatív } \\
\text { alosztályok }\end{array}$ & Foglalkozások & Tudás-bázis & FEOR kódok \\
\hline \multirow{2}{*}{$\begin{array}{l}\text { Kreatív irá- } \\
\text { nyítók }\end{array}$} & $\begin{array}{l}\text { Törvényhozók, képvise- } \\
\text { lők és felsővezetők }\end{array}$ & Politikus tudás & $\begin{array}{l}111-113 \\
121-123 \\
131\end{array}$ \\
\hline & Középvezetők & $\begin{array}{l}\text { Menedzsment v. } \\
\text { Szcenikus tudás }\end{array}$ & $132-134$ \\
\hline \multirow{4}{*}{ Kreatív mag } & $\begin{array}{l}\text { Élet-, természet- és mér- } \\
\text { nöki tudományokkal } \\
\text { foglalkozók }\end{array}$ & Analitikus tudás & $\begin{array}{l}211-214 ; 219 \\
221-222 ; 224\end{array}$ \\
\hline & $\begin{array}{l}\text { Jogászok, közgazdászok, } \\
\text { társadalomtudósok }\end{array}$ & $\begin{array}{l}\text { Szintetikus } \\
\text { tudás }\end{array}$ & $231 ; 251-254$ \\
\hline & $\begin{array}{l}\text { Múvészek, sportolók, } \\
\text { vallási- és kulturális } \\
\text { foglalkozásúak }\end{array}$ & $\begin{array}{l}\text { Szimbolikus } \\
\text { tudás }\end{array}$ & $\begin{array}{l}261-264 \\
371-373\end{array}$ \\
\hline & Egyetemi oktatók & $\begin{array}{l}\text { Integrált tudás } \\
\text { v. Esszenciális } \\
\text { tudás }\end{array}$ & 241 \\
\hline $\begin{array}{l}\text { Kreatív } \\
\text { szakemberek }\end{array}$ & $\begin{array}{l}\text { Termelésirányítók, kis- } \\
\text { szervezeti vezetők, tech- } \\
\text { nikusok, pedagógusok } \\
\text { stb. }\end{array}$ & $\begin{array}{l}\text { Alkalmazó v. } \\
\text { adaptív v. } \\
\text { Operacionális } \\
\text { tudás }\end{array}$ & $\begin{array}{l}135 ; 141-142 ; \\
223 ; 232-233 ; \\
243-244 ; 249 ; \\
291 ; 311-364 ; \\
391 ; 534\end{array}$ \\
\hline
\end{tabular}

Megjegyzés: A szcenikus színházi müszaki vezetö, akinek feladata az intézmény müszaki ügyeinek intézése, a teljes műszaki személyzet és a gondnokság dolgozóinak irányítása, valamint a hozzá tartozó létesítmény vagy létesítmények biztonságos üzemeltetése.

Forrás: Saját szerkesztés Ságvári-Lengyel B. (2008) alapján.

Ebben a tanulmányban amellett érvelünk, hogy teljesen más feladata van a kreatív irányítóknak és a kreatív magba tartozó munkaerőnek, és más a kreatív szakembereknek, másképpen hatnak egy térség innovációs teljesítményére (1. táblázat).

A kreativ irányitók képviselői és felsóvezetỏi közé tartoznak a törvényhozók, országos igazgatási és érdekképviseleti vezetők, önkormányzati képviselők, közigazgatási vezetők és a gazdasági, költségvetési szervek vezetői. Bár egészen más motivációk hajtják a kormányzati képviselöket, a költségvetési és gazdasági szervek vezetöit, célszerü őket együtt kezelni a tudásbázis modellezésénél. Ezek a szereplők az innováció és innovációs rendszer fejlődésének fő irányait adják meg, az alájuk tartozók érdekképviseletét látják el, egyformán véleményt nyilvánítanak gazdaságpolitikai kérdésekben stb. (Ezen túl a foglalkozások 3-as FEOR kódú besorolása nem teszi lehetôvé, hogy a 131-es osztályon belül megkülönböztessük a költségvetési és a gazdasági szervek vezetöit. Az 1311-es gazdasági szervezetek vezetöi- 
Lengyel Balázs - Ságvári Bence : Kreatív foglalkozások és regionális tudásbázis:

Fogalmak, folyamatok és területi összefüggések. - Tér és Társadalom 23. évf. 2009/4. 1-26. p.

nek és a 1312-es költségvetési szervek vezetőinek száma megközelítőleg azonos.) Az ö kreativitásuk legfőképpen arra irányul, hogy a városok, régiók, országok innovációs rendszereinek eróviszonyait átlássák, és a fö célokat kijelöljék. A képviselök és felsővezetők körei zártak, a kreatív irányítók tudásukat ezekben a hálózatokban osztják meg egymással. Jellemzően erős elkötelezettség szükséges ahhoz, hogy ezekbe a hálózatokba be lehessen kerülni.

A kreatív irányítók középvezetöi közé tartoznak a gazdasági és költségvetési szervek szakmai részegységeinek és funkcionális tevékenységet folytató részegységeinek vezetői. Nekik nem a célok kijelölésében, hanem azok elérésében kell kreatívnak lenniuik. Azt kell elérniük, hogy az egységuik hatékonyan müködjön, tudásuk tehát az egységek vezetésében, menedzsmentjében nyilvánul meg. A kreatív mag teremti egy város, régió, ország tudásbázisát, az innováció folyamatához ez a csoport adja a fỏ inputot. Kreativitásuk abban testesül meg, hogy új összefüggéseket, ismereteket tárjanak fel, az új ismereteket másokkal megosszák, $s$ ezzel új társadalmi és gazdasági viszonyokat teremtsenek. A kreatív mag összetett felépítése és múködése miatt a későbbiekben részletesebben is foglalkozunk velük. A kreativ szakemberek a saját elvégzett munkájukért felelnek, ezért kreativitásuk a konkrét munkavégzésben, a feladatok ellátásában kristályosodik ki. A kreatív szakembereket az különbözteti meg a szolgáltatásokban, az iparban és mezögazdaságban dolgozó többi munkavállalótól, hogy magasabb képzettséget igényelnek. (Florida az amerikai nagyvárosok kreatív osztályának vizsgálatánál a jogászokat és közgazdászokat is a kreatív szakemberek közé sorolta.) A kreatív szakemberek a munkavégzésre vonatkozó operacionális tudásukat a szervezeten belül osztják meg egymással.

Az innovációs rendszerek tudásbázisát a foglalkoztatottak statisztikai besorolása alapján jellemezzüik; a kreatív mag további elemzéséhez négy kategóriát különítettünk el: analitikus tudást, szintetikus tudást, szimbolikus tudást és esszenciális tudást. Az analitikus tudásbázisba mi a természettudósokat, orvosokat és mérnököket értjük, bár az eredeti definíció szerint a mérnökök a szintetikus tudásbázist alakítják. Viszont ők azok, akik tudásukat leginkább képesek globális szinten hasznosítani, azt más országokban is tudják kamatoztatni. A szintetikus tudásbázis helyhez kötött, arra véleményünk szerint a jogászok, közgazdászok és társadalomtudósok is alkotó módon hatnak. A szimbolikus tudásbázist a művészek és sportolók teremtik, a kulturális szervezök és könyvtárosok pedig munkájukkal az e tudáshoż való helyi hozzáférést segítik. Az esszenciális tudás az egyetemekhez köthető, az egyetemi oktatók speciális helyet töltenek be az innovációs rendszerben és a kreatív mag tudásteremtésében: kutatómunkájukkal új tudást állítanak elö, ugyanakkor az egész kreatív osztály számára a felsőfokú képzés során átadják az esszenciává sürített tudást.

Számos probléma felvetődik a foglalkozások fenti kategóriákba való besorolásánál, ezekre itt nem térünk ki. Úgy véljüik azonban, hogy a tudásbázis fenti kategóriái jól megragadják az innováció helyi és globális jellegét, hasznosak a gazdaságpolitika számára is, hiszen ezek teremtését eltérỏ elvek alapján kell támogatni. A kategóriák egymást kölcsönösen nem zárják ki, szerencsésebb azokat átfedő Venn-diagrammal ábrázolni (1.ábra). 


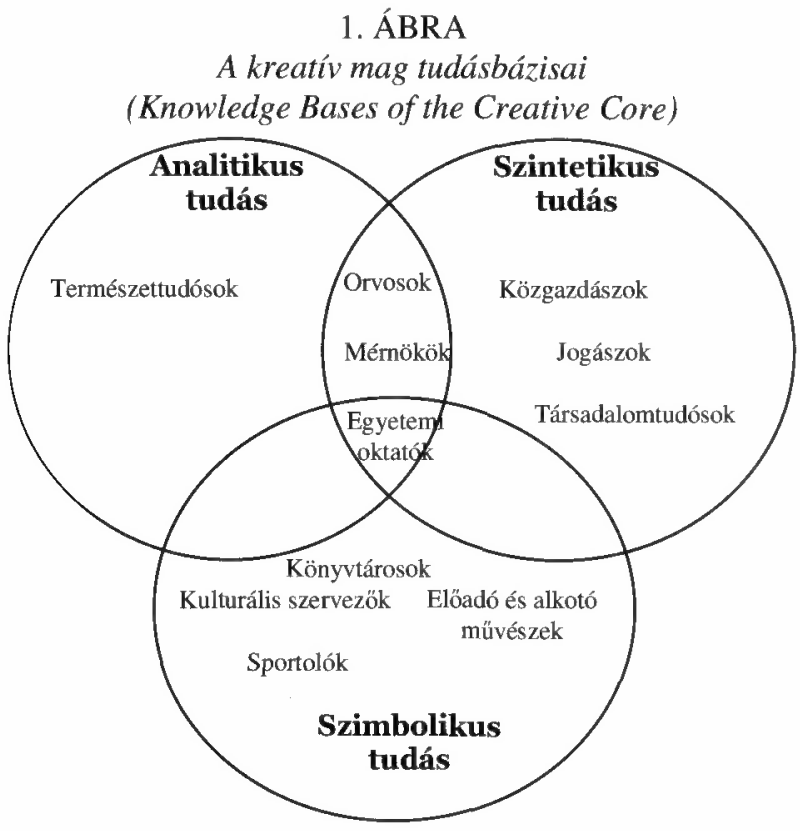

Forrás: Ságvári-Lengyel B. (2008).

A magyar területi vizsgálatban a fent kifejtett foglalkozási kategóriákat az egyetemi képzési szerkezettel együtt elemezzük. A foglalkozási osztályok az innovációs rendszer tudásbázisát, az egyetemi kategóriák a rendszer tudásbázis-teremtő képességét mérik. A két indikátort hasonló szerkezetben vettük számba: a 2001-2002-es tanév felsőoktatási alapszakjainak tudományterïleti besorolásait alkalmaztuk. Gondolatmenetünk alapján a természettudományi szakok analitikus, az élettudományi szakok egyaránt analitikus és szintetikus, a müszaki tudományi és agrártudományi szakok szintetikus, a társadalomtudományi szakok kvázi-szintetikus, a bölcsészettudományi, hittudományi és müvészeti szakok szimbolikus tudásbázis létrehozásában bírnak vezetö szereppel. A későbbiekben részletesen bemutatjuk az egyetemi képzési szerkezet területi jellemzőit is, a következő fejezetben azonban a hazai regionális innovációs rendszerek 1996 és 2005 közötti fejlödését összegezzuik a foglalkozási kategóriák alapján.

\section{A kreativ munkavégzés és tudásbázis térben és időben}

A kreatív munkavégzés elmúlt évtizedben végbement területi koncentrációváltozásának elemzéséhez megyei adatok álltak rendelkezésünkre. Az 1996-os és 2005-ös mikrocenzus adatfelvételei csak ezen a területi szinten reprezentatívak, ugyanakkor a 2001-es népszámlálás adatait a kistérségek szintjén is fel tudtuk dolgozni. A kistérségi adatokat használtuk a később kifejtésre kerülö regressziós modellünkben, a modell eredményeit pedig a megyei szintú, évtizednyi változást követő adatokkal magyarázzuk. 
Lengyel Balázs - Ságvári Bence : Kreatív foglalkozások és regionális tudásbázis:

Fogalmak, folyamatok és területi összefüggések. - Tér és Társadalom 23. évf. 2009/4. 1-26. p.

8 Lengyel Balázs - Ságvári Bence

TÉT XXIII. évf. 2009 - 4

\section{TÁBLÁZAT}

A kreativ osztály megyei mérete, összes foglalkoztatotthoz mért aránya, 1996, 2001, 2005

(Creative Class in the Hungarian Counties, 1996, 2001, 2005)

\begin{tabular}{|c|c|c|c|c|c|c|c|c|c|}
\hline \multirow{2}{*}{ Megyék } & \multicolumn{3}{|c|}{1996} & \multicolumn{3}{|c|}{2001} & \multicolumn{3}{|c|}{2005} \\
\hline & Kreativ & Összes & $\%$ & Kreativ & $\ddot{O}_{\text {sszes }}$ & $\%$ & Kreativ & Összes & $\%$ \\
\hline Budapest & 333045 & 708893 & 47 & 383123 & 746018 & 51 & 415359 & 754957 & 55 \\
\hline $\begin{array}{l}\text { Baranya } \\
\text { Borsod- }\end{array}$ & 42589 & 131894 & 32 & 47276 & 136390 & 35 & 51936 & 143957 & 36 \\
\hline $\begin{array}{l}\text { Abaúj- } \\
\text { Zemplén }\end{array}$ & 38248 & 150406 & 25 & 73051 & 209307 & 35 & 74763 & 220316 & 34 \\
\hline $\begin{array}{l}\text { Bács- } \\
\text { Kiskun }\end{array}$ & 47486 & 188138 & 25 & 51419 & 191550 & 27 & 58413 & 199218 & 29 \\
\hline Békés & 33801 & 125570 & 27 & 36770 & 125151 & 29 & 42266 & 129863 & 33 \\
\hline Csongrád & 44288 & 152961 & 29 & 50545 & 154174 & 33 & 55883 & 156735 & 36 \\
\hline $\begin{array}{l}\text { Fejér } \\
\text { Gyór- }\end{array}$ & 41678 & 155791 & 27 & 52633 & 175433 & 30 & 60053 & 177024 & 34 \\
\hline $\begin{array}{l}\text { Moson- } \\
\text { Sopron }\end{array}$ & 50472 & 170064 & 30 & 56433 & 184389 & 31 & 61115 & 184494 & 33 \\
\hline $\begin{array}{l}\text { Hajdú- } \\
\text { Bihar }\end{array}$ & 51376 & 165925 & 31 & 58018 & 174794 & 33 & 66074 & 190490 & 35 \\
\hline $\begin{array}{l}\text { Heves } \\
\text { Jász- }\end{array}$ & 31101 & 105975 & 29 & 34548 & 110041 & $3 I$ & 41081 & 115026 & 36 \\
\hline $\begin{array}{l}\text { Nagykun- } \\
\text { Szolnok }\end{array}$ & 36556 & 131926 & 28 & 40945 & 133519 & 31 & 47380 & 141249 & 34 \\
\hline $\begin{array}{l}\text { Komárom- } \\
\text { Esztergom }\end{array}$ & 29536 & 107422 & 27 & 37230 & 123971 & 30 & 41735 & 131162 & 32 \\
\hline Nógrád & 18483 & 65215 & 28 & 21153 & 72672 & 29 & 23492 & 76067 & 31 \\
\hline Pest & 99489 & 357917 & 28 & 141208 & 416624 & 34 & 171458 & 471669 & 36 \\
\hline $\begin{array}{l}\text { Somogy } \\
\text { Szabolcs- }\end{array}$ & 29491 & 108758 & 27 & 34457 & 112498 & 31 & 33725 & 112066 & 30 \\
\hline $\begin{array}{l}\text { Szatmár- } \\
\text { Bereg }\end{array}$ & 40248 & 151302 & 27 & 49544 & 157445 & 31 & 58349 & 173576 & 34 \\
\hline Tolna & 24179 & 84723 & 29 & 26039 & 87908 & 30 & 28801 & 90044 & 32 \\
\hline Vas & 28090 & 110377 & 25 & 32103 & 114846 & 28 & 34684 & 109097 & 32 \\
\hline Veszprém & 36745 & 137245 & 27 & 42654 & 145925 & 29 & 48068 & 147671 & 33 \\
\hline Zala & 31043 & 115754 & 27 & 34623 & 117614 & 29 & 38034 & 121705 & 31 \\
\hline $\begin{array}{c}\text { Ország } \\
\text { összesen }\end{array}$ & 1087944 & 3426256 & 32 & 1303772 & 3690269 & 35 & 1452669 & 3846.386 & 38 \\
\hline
\end{tabular}

Forrás: Ságvári-Lengyel B. (2008).

Magyarországon Budapest súlya a kreatív osztály koncentrációjában kiemelkedően magas, 1996-ban a kreatívok 31, 2001-ben és 2005-ben 29\%-a élt a fövárosban, Pest megyében 9, 11 és 12\%-a. A kreatív osztály növekedése 1996 és 2005 között területileg differenciáltan zajlott. Borsod-Abaúj-Zemplén megye növekedési rátája a legmagasabb, itt majdnem megduplázódott a kreatív munkaerő, Budapesten 72\%-kal nőtt. Szabolcs-Szatmár-Bereg, Komárom-Esztergom és Fejér megye növekedése emelkedik ki az országban. A növekedés Észak-Magyarországon, az ÉszakAlföldön és Közép-Dunántúlon dinamikusabb, a Dél-Alföldön, Nyugat- és DélDunántúlon lassabb volt (2. táblázat).

A kreatív osztálynak az egyes megyék teljes munkaerőn belüli arányait tekintve az 1996-tól 2005-ig tartó időszakban, az egész országban általános a növekedés: Budapesten például ez az arány 47\%-ról 55\%-ra nött (miközben az országos érték is 
32\%-ról 38\%-ra emelkedett). A növekedő tendenciákból csak néhányat emelünk ki: Borsod-Abaúj-Zemplénben (Miskolc szerepének köszönhetően) az 1996-2001 közötti időszakban közel 10 százalékponttal nőtt a kreatívok aránya, a foglalkoztatottak száma pedig mintegy 70 ezerrel, s ezen belül a kreatív osztály tagjainak száma 36,5 ezerrel. Az 1996-tól 2005-ig terjedő időszakban, szinte az összes megyében átlépte a kreatív osztályban foglalkoztatottak aránya az egyharmadot, és BorsodAbaúj-Zemplén mellett jó néhány megyében (pl. Csongrád, Fejér, Heves, SzabolcsSzatmár-Bereg) szintén igen magas, akár 7 százalékpontos is volt a kreatív osztály arányának növekedése a vizsgált évtized alatt.

A kreatív osztály idóbeli változásával kapcsolatban sajátos észak-dél megosztottságot láthatunk az ország területén. A kreatív osztály domináns fővárosi koncentrációja és dinamikus növekedése mellett a kreatív osztály egy képzeletbeli északkeleti tengely mellett nőtt: Borsod-Abaúj-Zemplén megyében kiugró mértékben nőtt, amely dinamikát csak a komáromi és székesfehérvári fejlődés közelíti meg (2. ábra). A kreatív osztály fö kategóriái ugyanakkor hasonló megoszlásokat mutatnak a megyékben: a kreatív szakértők alkotják a megyei kreatív munkaerő kétharmadát, a maradék egyharmadot a kreatív irányítók és kreatív mag fele-fele arányban teszik ki az összes megyében.

\section{2. ÁBRA}

A kreatív osztály összetétele 2005-ben és növekedése 1996-tól 2005-ig

(Growth and Structure of the Creative Class)
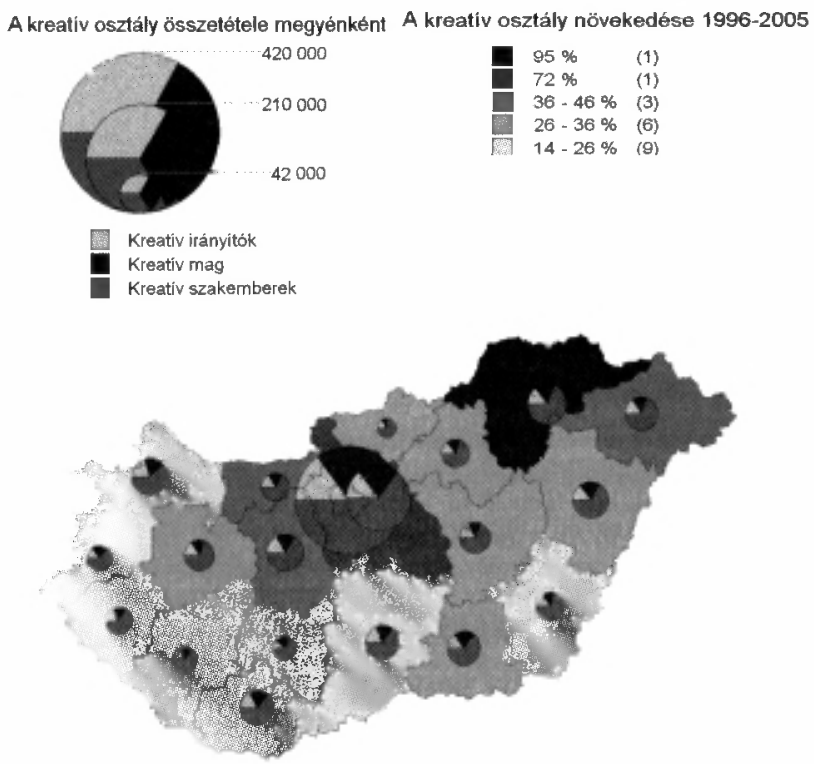

Forrás: Ságvári-Lengyel B. (2008).

A kreatív mag az önálló tudásteremtő képessége miatt az innovációs rendszer megújuló-képességének bázisát jelenti. A kreatív mag analitikus, szintetikus, szimbolikus és integrált tudásbázisainak megoszlása és változásuk tendenciái térség-specifikusak. 
Lengyel Balázs - Ságvári Bence : Kreatív foglalkozások és regionális tudásbázis:

Fogalmak, folyamatok és területi összefüggések. - Tér és Társadalom 23. évf. 2009/4. 1-26. p.

10 Lengyel Balázs - Ságvári Bence

TÉT XXIII. évf. 2009 — 4

\section{3. ÁBRA}

A kreatív mag összetétele és kreativ osztályon belüli aránya, 2005

(Structure of the Creative Core and its Share in the Creative Class, 2005)

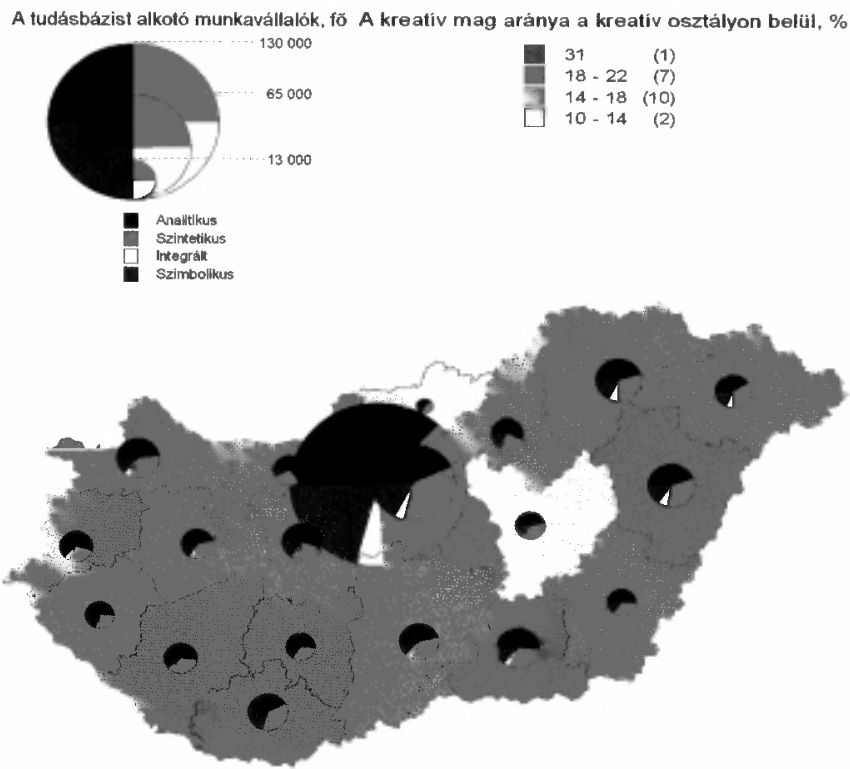

Forrâs: Ságvári-Lengyel B. (2008).

A kreatív mag Budapesten és agglomerációjában koncentrálódik, és feltủnö, hogy az ország keleti megyéiben nagyobb méretben van jelen, mint a gazdaságilag fejlettebb nyugati megyékben (3. ábra). Az analitikus tudásbázis a kreatív mag 40-50\%-a, a szintetikus tudásbázis ennél kisebb arányú, mintegy $25-30 \%$, a szimbolikus tudásbázis a kreatív mag 10-15\%-a, az integrált tudásbázis pedig érdemben csak a nagyobb egyetemmel, főiskolával rendelkező térségekben jelenik meg, a kreatív magnak értelemszerüen csak kisebb részét adja. A fentiekhez képest Budapest és Pest megye értékei más megoszlást mutatnak: az agglomerációban a szintetikus tudásbázis nagyon erős, az analitikus tudásbázissal hasonló méretủ, a szimbolikus tudásbázis pedig jóval nagyobb arányú, mint az ország többi részében.

A kreatív mag összetétele mellett az analitikus és szintetikus tudásbázis növekedésének eltérö irányai figyelhetők meg az országban, melyeket alább részleteiben is bemutatunk.

\section{Az analitikus tudásbázis}

Az analitikus tudásbázisba a mérnökök, orvosok és a természettudományokkal foglalkozók tartoznak. Az ő tudásuk kevéssé kötődik a helyi viszonyokhoz, könynyen konvertálható az egész világon, ezért bárhol tudnak munkát vállalni. Így a magyar orvosok, mérnökök, kémikusok, biológusok stb. tudásukat akár nemzetközi szinten is képesek mobilizálni, erre az analitikus tudásbázis fejlesztésekor figyelemmel kell lenni. Az analitikus tudásbázis képezi a leginkább mobil, a környezeti 
feltételekre legérzékenyebb munkaeröt. Nem véletlen, hogy az innovációs politika és a tudásalapú gazdaságfejlesztés elsősorban erre a tudásbázisra koncentrál.

Az analitikus tudásbázis csökkenő mértékben, persze így is meghatározó módon koncentrálódik Budapesten, az agglomeráció szerepe egyre nő. Meg kell azonban említenünk, hogy csalóka az itt kapott kép: a népszámlálás és a mikrocenzusok adatfelvételei a lakóhelyre vonatkoztak, így valószínủleg jóval többen dolgoznak az analitikusok közül Budapesten, akiknek lakhelye másik település. A megyék analitikus tudásbázisa többféle módon változott a vizsgálatunk 10 éves időtartama alatt, a növekedés korántsem általános tendencia.

\section{TÁBLÁZAT}

Az analitikus tudásbázis területi értékei

(Volume of Analytic Knowledge Base in the Hungarian Counties)

\begin{tabular}{|c|c|c|c|c|c|c|c|c|c|}
\hline \multirow[t]{2}{*}{ Megye } & \multicolumn{3}{|c|}{$\begin{array}{c}\text { A tudásbázist alkotók } \\
\text { száma (fö) }\end{array}$} & \multicolumn{3}{|c|}{$\begin{array}{c}\text { A helyi bázis aránya } \\
\text { az országban (\%) }\end{array}$} & \multicolumn{3}{|c|}{$\begin{array}{l}\text { Az analitikus bázis } \\
\text { helyi kreatív magon } \\
\text { belüli aranya }(\%)\end{array}$} \\
\hline & 1996 & 2001 & 2005 & 1996 & 2001 & 2005 & 1996 & 2001 & 2005 \\
\hline Budapest & 42549 & 50318 & 47657 & 38 & 37 & 35 & 40 & 41 & 37 \\
\hline Baranya & 4151 & 4759 & 4109 & 4 & 4 & 3 & 46 & 46 & 43 \\
\hline $\begin{array}{l}\text { Borsod-Abaúj- } \\
\text { Zemplén }\end{array}$ & 2378 & 6472 & 5776 & 2 & 5 & 4 & 52 & 51 & 45 \\
\hline Bács-Kiskun & 3205 & 4355 & 4756 & 3 & 3 & 4 & 44 & 48 & 47 \\
\hline Békés & 2169 & 2895 & 3051 & 2 & 2 & 2 & 40 & 49 & 51 \\
\hline Csongrád & 4522 & 5514 & 6060 & 4 & 4 & 4 & 44 & 47 & 51 \\
\hline Fejér & 4591 & 4999 & 5681 & 4 & 4 & 4 & 59 & 54 & 56 \\
\hline $\begin{array}{l}\text { Györ-Moson- } \\
\text { Sopron }\end{array}$ & 5122 & 5598 & 5189 & 5 & 4 & 4 & 55 & 51 & 49 \\
\hline Hajdú-Bihar & 6159 & 5806 & 5450 & 5 & 4 & 4 & 51 & 48 & 45 \\
\hline Heves & 2733 & 2997 & 3904 & 2 & 2 & 3 & 50 & 49 & 57 \\
\hline $\begin{array}{l}\text { Jász-Nagykun- } \\
\text { Szolnok }\end{array}$ & 3146 & 3397 & 2808 & 3 & 3 & 2 & 54 & 49 & 47 \\
\hline $\begin{array}{l}\text { Komárom- } \\
\text { Esztergom }\end{array}$ & 2347 & 3262 & 4466 & 2 & 2 & 3 & 45 & 51 & 65 \\
\hline Nógrád & 1114 & 1551 & 949 & 1 & 1 & 1 & 42 & 49 & 40 \\
\hline Pest & 10905 & 13674 & 15388 & 10 & 10 & 11 & 54 & 46 & 43 \\
\hline Somogy & 2190 & 2836 & 3349 & 2 & 2 & 2 & 35 & 48 & 51 \\
\hline $\begin{array}{l}\text { Szabolcs- } \\
\text { Szatmár-Bereg }\end{array}$ & 3803 & 3947 & 3487 & 3 & 3 & 3 & 52 & 49 & 42 \\
\hline Tolna & 2753 & 2427 & 2793 & 2 & 2 & 2 & 67 & 57 & 52 \\
\hline Vas & 2349 & 2721 & 3674 & 2 & 2 & 3 & 58 & 50 & 55 \\
\hline Veszprëm & 3527 & 3860 & 3375 & 3 & 3 & 2 & 55 & 51 & 47 \\
\hline Zala & 2750 & 3194 & 3240 & 2 & 2 & 2 & 57 & 52 & 51 \\
\hline Ország összesen & 112463 & 134582 & 135162 & 100 & 100 & 100 & 46 & 46 & 44 \\
\hline
\end{tabular}

Forrás: Ságvári-Lengyel B. (2008).

$\mathrm{Az}$ analitikus tudásbázis növekedése a tudásbázis helyi, kreatív magon belüli arányát Bács-Kiskun, Békés, Csongrád, Komárom-Esztergom és Somogy megyékben növelte. $\mathrm{Az}$ analitikus tudásbázis abszolút értékủ növekedése lassabb volt a többi tudásbázis helyi növekedésénél Budapesten, Borsod-Abaúj-Zemplén, Fejér, Györ- 
Moson-Sopron, Heves, Pest, Vas és Zala megyékben (3. táblázat). Ezekben a megyékben az analitikus tudásbázis szerepe gyengült a helyi innovációs rendszer belső viszonyait tekintve. Még rosszabb a helyzet Hajdú-Bihar, Jász-NagykunSzolnok, Nógrád, Szabolcs-Szatmár-Bereg, Tolna- és Veszprém megyékben, ahol az analitikus tudásbázis abszolút értékben is csökkent.

Az analitikus tudásbázis csökkenése esetén kisebb annak a valószínűsége, hogy a térségből olyan innovációk kerüljenek ki, amelyek a globális piac értékláncába tudnának illeszkedni. Amennyiben a térségben az analitikus tudásbázis arányai csökkennek, akkor a tudásbázis helyi érdekérvényesítỏ képessége is csökken, így a fejlesztési célok és források valószínủleg más tudásbázisokat erősítenek. Az analitikus tudásbázis méretének és arányainak egyidejủ növekedésével ugyanakkor az innovációk megjelenésének valószínüsége növekszik, amit a helyi innovációs rendszer is növekvő mértékben támogat.

\section{Szintetikus tudásbázis}

A szintetikus tudásbázis fundamentumát azok a jogászok, közgazdászok és társadalomtudósok alkotják, akik tudása föleg helyi, lokális viszonyok között értelmezhetô. Az ő tudásuk az innovációk gazdasági és társadalmi hasznosítására irányul, nélkülözhetetlenek abban, hogy akár a helyi, akár a globális szinten elóállított javakat és a szolgáltatásokat piacra lehessen juttatni. Ök az innovációs rendszert nem müszaki és tudományos újitások létrehozásán keresztül alakítják, hanem elsősorban a gazdasági cserefolyamatok lebonyolításán, a jogi-szabályozási környezet múködtetésén és a társadalmi valóság, a jelen és a múlt, az emberi viszonyok megismerésén keresztuil. Ezért koncentrációjuk változása többnyire arról ad információt, hogy az adott térségek erősödnek vagy gyengülnek a nemzeti innovációs rendszer gazdasági és társadalmi alrendszereiben. Másrészt helyi arányuk növekedéséből arra is következtethetünk, hogy a térségben a tudás gazdasági hasznosítása gyorsabban fejlődik, mint a klasszikus értelemben vett tudományos és müszaki tudás- és értékteremtés.

A szintetikus tudásbázis egyre növekvő mértékben koncentrálódik Budapesten és az agglomerációjában (4. táblázat). 1996-tól 2005-ig minden megyében növekedett az ebben a tudásbázisban foglalkoztatottak száma, azonban a fóvárosi agglomeráció dinamikája mögött ezek a változások messze elmaradnak. Érdemes még megemlíteni, hogy Békés, Nógrád és Somogy megyében ugyanekkor csökkent a szintetikus tudásbázis koncentrációja. A szintetikus tudásbázis helyi arányai Budapesten és Pest megyében, illetve Győr-Moson-Sopron, Hajdú-Bihar, Jász-Nagykun-Szolnok, Szabolcs-Szatmár-Bereg, Tolna és Vas megyékben nőttek. Ezekben a megyékben egyértelmú igazán, hogy a tudás gazdasági hasznosítása gyorsabban fejlödött, mint az a tudásteremtés, amely az újdonságokat szállítja. 
Lengyel Balázs - Ságvári Bence : Kreatív foglalkozások és regionális tudásbázis:

Fogalmak, folyamatok és területi összefüggések. - Tér és Társadalom 23. évf. 2009/4. 1-26. p.

TÉT XXIII. évf. 2009 a 4

Kreatív foglalkozások és ... 13

\section{TÁBLÁZAT}

A szintetikus tudásbázis megyei értékei

(Volume of Synthetic Knowledge Base in the Hungarian Counties)

\begin{tabular}{|c|c|c|c|c|c|c|c|c|c|}
\hline \multirow[t]{2}{*}{ Megye } & \multicolumn{3}{|c|}{$\begin{array}{c}\text { A tudásbázist alkotó } \\
\text { foglalkoztatottak } \\
\text { száma (fó) }\end{array}$} & \multicolumn{3}{|c|}{$\begin{array}{c}\text { A helyi bázis } \\
\text { aránya az ország- } \\
\text { ban }(\%)\end{array}$} & \multicolumn{3}{|c|}{$\begin{array}{c}\text { A szintetikus bázis } \\
\text { aránya a helyi } \\
\text { magban }(\%)\end{array}$} \\
\hline & 1996 & 2001 & 2005 & 1996 & 2001 & 2005 & 1996 & 2001 & 2005 \\
\hline Budapest & 31388 & 41043 & 47454 & 43 & 45 & 45 & 30 & 33 & 37 \\
\hline Baranya & 2812 & 2980 & 3044 & 4 & 3 & 3 & 31 & 29 & 31 \\
\hline $\begin{array}{l}\text { Borsod-Abaúj- } \\
\text { Zemplén }\end{array}$ & 1539 & 3622 & 3786 & 2 & 4 & 4 & 34 & 28 & 30 \\
\hline Bács-Kiskun & 2623 & 2851 & 3460 & 4 & 3 & 3 & 36 & 31 & 34 \\
\hline Békés & 2200 & 1813 & 1926 & 3 & 2 & 2 & 41 & 31 & 32 \\
\hline Csongrád & 3244 & 3174 & 3556 & 4 & 3 & 3 & 32 & 27 & 30 \\
\hline Fejér & 1956 & 2494 & 2458 & 3 & 3 & 2 & 25 & 27 & 24 \\
\hline $\begin{array}{l}\text { Gyỏr-Moson- } \\
\text { Sopron }\end{array}$ & 2404 & 3081 & 3403 & 3 & 3 & 3 & 26 & 28 & 32 \\
\hline Hajdu-Bihar & 2946 & 3234 & 3918 & 4 & 4 & 4 & 24 & 27 & 32 \\
\hline Heves & 1646 & 1853 & 1654 & 2 & 2 & 2 & 30 & 30 & 24 \\
\hline $\begin{array}{l}\text { Jász-Nagykun- } \\
\text { Szolnok }\end{array}$ & 1468 & 2251 & 2204 & 2 & 2 & 2 & 25 & 32 & 37 \\
\hline $\begin{array}{l}\text { Komárom- } \\
\text { Esztergom }\end{array}$ & 1848 & 2078 & 1886 & 3 & 2 & 2 & 35 & 33 & 27 \\
\hline Nógrád & 956 & 1031 & 850 & 1 & 1 & 1 & 36 & 33 & 36 \\
\hline Pest & 6014 & 9460 & 12685 & 8 & 10 & 12 & 30 & 32 & 36 \\
\hline Somogy & 2388 & 1651 & 2199 & 3 & 2 & 2 & 38 & 28 & 34 \\
\hline $\begin{array}{l}\text { Szabolcs- } \\
\text { Szatmár-Bereg }\end{array}$ & 1976 & 2327 & 38 & 3 & 3 & 3 & 27 & 29 & 33 \\
\hline Tolna & 922 & 1073 & 1689 & 1 & 1 & 2 & 22 & 25 & 31 \\
\hline Vas & 886 & 1437 & 1867 & 1 & 2 & 2 & 22 & 27 & 28 \\
\hline Veszprém & 1920 & 2130 & 2201 & 3 & 2 & 2 & 30 & 28 & 31 \\
\hline Zala & 1456 & 1733 & 1578 & 2 & 2 & 2 & 30 & 28 & 25 \\
\hline Ország összesen & 72592 & 91316 & 104556 & 100 & 100 & 100 & 30 & 31 & 34 \\
\hline
\end{tabular}

Forrás: Ságvári-Lengyel B. (2008).

Értelmezésünkben a budapesti szintetikus tudásbázis kiugró erősödése összefüggésben áll a nagyvárosi agglomeráció nemzetközi szerepének növekedésével. A külföldi nagyvállalatok megjelenése és a nemzetközi tranzakciók felerősödése serkentỏen hatott a sokszínü fơvárosi agglomerációra. Budapest, mint az „ország kapuja” kinyílt, része lett a globális hálózatoknak, így a fôváros innovációs rendszerében organikus folyamatként ment végbe a helyi beágyazottságot növelö, lokális gazdasági és társadalmi tudást integráló szintetikus tudásbázis növekedése.

\section{A $3 T$ regressziós modell és nemzetközi tapasztalatai}

Richard Floridának az USA nagyvárosaira vonatkozó módszertanát nehezen lehet alkalmazni Európában. Egészen más a kreatív munkaerô városok közötti mobilitása az Európai Unió szintjén, a nemzetgazdaságokon belül pedig általában néhány 
centrum, növekedési pólus vonzza a kreatív embereket. Több tanulmány is született, amelyben a kreatív osztályt nemzeti szinten vizsgálták (Florida-Tinagli 2004; Ságvári-Dessewffy 2006). Ahhoz azonban, hogy területi összefüggéseket tudjunk kimutatni, a munkaerő-vonzáskörzetek szintjén kell a kreatív munkavégzés jellemzőit megragadnunk. Munkaerö-vonzáskörzetnek az a területi egység tekinthetô, amelyen belül a munkavállaló munkahelyet tud cserélni anélkül, hogy el kelljen költöznie lakhelyéról (Lengyel 1.-Rechnitzer 2004).

Mellander és Florida (2007) a svéd munkaerö-vonzáskörzetek szintjén (81 svéd régió) vizsgálták a térségek tolerancia-szintje, a térségekben dolgozó kreatívok aránya, a térség gazdaságának technológiai fejlettsége és a térség általános fejlettsége közötti kapcsolatot. Modelljük érdekessége, hogy figyelembe vették azt is, hogy van-e a vonzáskörzetben egyetem, illetve a szolgáltatások milyen széles körét tudja a térség biztosítani a polgárai számára. A szerzők legújabb, amerikai nagyvárosokra alkalmazott modelljében a munkaerő-vonzáskörzetek tolerancia-szintjére és a régióban megtalálható szolgáltatások sokszínúségére vezetik vissza a térség kreatív osztályt és magas technológiájú iparágakat vonzó képességét (Florida et al. 2008). A tanulmányban amellett ẹrvelnek, hogy a regionális növekedést a tolerancia-szint, a képzett munkaeró és a térségben található iparágak technológiai színvonala határozza meg. A modell szerint az egyetemeknek nincs közvetlen hatásuk a térség életszínvonalára és az iparágak technológiai szintjére, csak a humán tôke képzésén keresztuil hatnak a regionális növekedésre.

Mindkét modell alapján elvégeztük a vizsgálatot, és azt találtuk, hogy az egyetemek jelenléte a legtöbb esetben nem magyarázza a kistérségek közötti jövedelemkülönbségeket. Ezért itt azokat az eredményeket mutatjuk be, ahol a kistérség tolerancia-szintje közvetlenül magyarázza a kreatív munkaerô, a technológia színvonal és a regionális fejlettség változóit. Az általunk vizsgált modell három regressziós egyenlet segítségével rajzolható fel, e szerint az egyetemek a kistérség kreatív munkaerején keresztül hatnak a régió gazdaságának technológiai színvonalára és a terület lakosságánál mért életszínvonalra (Florida et al. 2008):

Tehetség $=\beta_{11}$ Egyetem $+\beta_{12}$ Tolerancia $+\beta_{13}$ Kulturális Szolgáltatások $+\epsilon_{1}$ Technológia $=\beta_{21}$ Tolerancia $+\beta_{22}$ Tehetség + Kulturális Szolgáltatások $+C_{2}$ Regionális Fejlödés $=\beta_{31}$ Tolerancia $+\beta_{32}$ Tehetség $+\beta_{33}$ Technológia $+\epsilon_{3}$

A három regressziós egyenletből felrajzolt modell a régiók fejlődésének általános keretét alkotja (4. ábra). A modell függő változója a régióban mért életszínvonal szintje, melyet az egy fơre eső jövedelemmel, illetve az egy före esó bértömeggel mértek. A gondolati vezérelv szerint minél nyitottabb, toleránsabb egy térség, annál jobban vonzza a tehetségeket („kreativokat”), ami összességében pozitívan hat a magas technológiai szintet képviseló vállalatok letelepedésére, így magasabb jövedelemszintet várhatunk. A technológiai szint becslésére a high-tech iparágak lokációs hányadosát használták. A tehetségek számbavétele kétféleképpen történt: egyrészt a felsőfokú végzettséggel rendelkezỏ lakosok arányắt számolták, másrészt a kreatív osztályt 
alkotó foglalkoztatottak arányát mérték. A tolerancia-szint becslése a svéd modellben egy homoszexuális szervezet városokra vonatkozó rangsora alapján történt.

A modellben külön vizsgálták az egyetemek jelenlétének és a térségben igénybe vehetỏ szolgáltatásoknak a kreatív osztályra gyakorolt hatását. A szolgáltatások változatossága a modell szerint hat a térség toleranciájára, a tehetséges munkavállalók letelepedésére, illetve a technológiai színvonalra is. A vonzáskörzetekben elérhetỏ szolgáltatások változatosságát a térségben bejegyzett személyi szolgáltatások ágazati kódjainak számával mérték. Az egyetem változót az ezer före eső egyetemi karok száma jelentette.

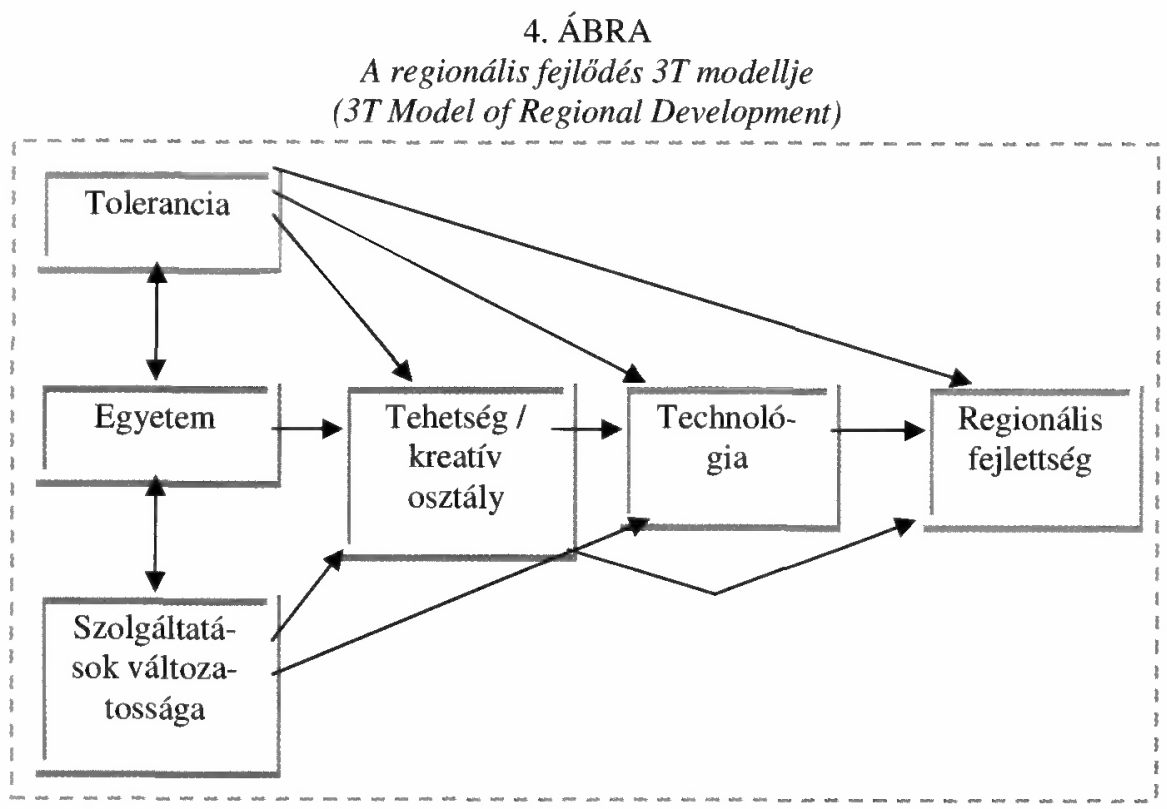

Forrás: Florida et al. $(2008,622)$.

A modell igazi érdekessége a tehetség mutató elemeire bontásában rejlik. Egyrészt össze lehet hasonlítani a kreatívok regionális fejlettségre való hatását az oktatási és a foglalkoztatási oldalról közelítve. A foglalkoztatási adatokon belül a szúken értelmezett „,szuperkreatívok” (super-creatives) és a tágabban értelmezett „kreatív szakértők" (creative professionals) csoportjait különítették el (Florida et al. 2008). A „szuperkreatív” csoportot tovább bontották múvészekre, természet- és társadalomtudósokra, informatikusokra, mérnökökre. Úgy véljük azonban, hogy a modell hazai adaptálása során többre van szükség a fenti osztályozás egyszerú követésénél, ezért a fejezet elöző részeiben kifejtett kategóriákra is alkalmaztuk a gondolatmenetet. 


\section{A hazai vizsgálat és eredményei}

$\mathrm{Az}$ általunk elvégzett magyar vizsgálat a KSH-tól egyéni adatkérés során szerzett adatokon alapul. Elemzésünket megpróbáltuk a lehető legkisebb területi szinten végrehajtani, ami szükségképpen számos kompromisszum megkötését is jelentette. Kistérségi szinten voltunk kíváncsiak a lakosság foglalkoztatási összetételére, ezért a 2001-es népszámlálás adatait tudtuk csak felhasználni. Az adatokból általunk számított mutatóink a kistérségek fejlettségére, technológiai színvonalára, a kreatív foglalkozásúakra, a munkaerỏpiac nyitottságára, a felsőfokú oktatási intézmények jelenlétére és az elérhető szolgáltatások sokszínüségére vonatkoznak.

A térségek fejlettségének általánosan elfogadott indikátora a lakosság jövedelemszerzö-képessége, az egy főre eső jövedelem. Az összesített személyi jövedelemadóalap összegét osztottuk az adófizetök számával; az aktív népesség jövedelemszerző képességét becsuiltuik ezzel. A kistérségek technikai fejlettségét az ott koncentrálódó high-tech és medium-tech ágazatokkal közelítettük meg, az ezen ágazatokban foglalkoztatottak számát viszonyítottuk a teljes gazdasághoz (ipar + agrárium + tercier szektor). Az egyetem mutatónál az adott kistérségben foglalkoztatottak számához viszonyítottuk az ottani felsỏoktatási intézményekben nappali tanulmányokat végzők számát. A szolgáltatások sokszínúségét a szerint határoztuk meg, hogy a 92-es szolgáltatási TEÁOR ág 14 osztályából számszerủen mennyiből jegyeztek be legalább egy céget a kistérségben.

A kreativ munkaerỏ megragadása két módon lehetséges: képzési adatok, illetve foglalkoztatási adatok által. A képzettség oldaláról a felsőfokú végzettséggel rendelkező munkavállalókat vettük figyelembe. A foglalkoztatási oldalról a szervezeten belüli érvényesülést kereső, az érdeklődését, önkifejezését követő és az önálló döntéshozatalában korlátozott munkaerô archetípusait különböztettük meg. A kreatív irányítók, kreatív mag és kreatív alkalmazók csoportjainak megkülönböztetése erre a logikára épül.

A városok kreatív munkaerőt vonzó atmoszférája igen nehezen számszerủsíthető. Richard Florida (2002a; 2002b) a városokban élő homoszexuálisok arányát számolta ki, majd használta annak illusztrálására, hogy mennyire be- és elfogadó egy település, hogyan jellemezhető a mássághoz való általános hozzáállás, az ezzel kapcsolatos tolerancia. Más vizsgálatokban több példát találunk arra, hogy a toleranciával kapcsolatos mutatókhoz a bevándorlók, a külföldi munkavállalók arányát vizsgálják. Ennek alkalmazása szintén problémás Magyarország esetében, hiszen az amerikai, vagy akár a svéd munkaeröpiaccal összehasonlítva is igen alacsony a külföldi munkavállalók aránya, vagy éppen igazi kihívás elé állítja a statisztikusokat számbavételük (pl. a Magyarországon élő kínaiak esetében). A magyar városok, térségek munkaerőpiacát jellemző nyitottság mérésére mégis ezt a megközelítést alkalmaztuk. A 2001 -es népszámlálás adataiból a külföldi állampolgárságú foglalkoztatottak loká- 
ciós hányadosát számoltuk ki a hazai kistérségekben. Ez a koncentrációs mutató a munkavállalók lakóhelyére vonatkozik. A speciális magyar helyzetből adódóan (pl. határon túli magyarok munkavállalása) nem állíthatjuk, hogy a mutató tökéletesen be tudja tölteni a tolerancia mérésének szerepét. Úgy véljük azonban, hogy az indikátor legalább részleges képet nyújt a munkaerőpiac nyitottságáról.

A regionális fejlettség és a modell független változói közötti kapcsolatokból a legérdekesebbeket emeljük ki (5. táblázat). A legerősebb kapcsolat a humán tőke $(0,728)$, a kreatív mag $(0,786)$, illetve a teljes kreatív osztály $(0,748)$ esetében figyelhetô meg (5. táblázat). Egy kistérség gazdasági fejlettségét jobban magyarázza a kreatív mag csoportjának nagyarányú jelenléte, mint a felsőfokú végzettségúek vagy a kreatív alkalmazók jelenléte. A felsőfokú végzettségủek természetesen nagy részben fedik a kreatív osztály csoportjait, hiszen a kreatív foglalkozások döntő részben felsőfokú végzettséget igényelnek (lásd pl. humán tőke és kreativ csoportok közötti korrelációt). Érdemes kiemelni, hogy a területileg koncentrált felsőoktatás (akár az oktatók, akár a nappali tagozatos hallgatók számát tekintve) igen jelentősen együtt mozog a felsőfokú végzettséggel rendelkező foglalkoztatottak és a kreatív mag nagyságával. Más szóval, a képzett és önmegvalósításra törekvő munkaerő nagyrészt a felsőoktatási intézménnyel rendelkezö kistérségekben koncentrálódik.

Egy kistérség gazdaságának technológiai színvonala és a regionális fejlettség közötti kapcsolat mérése a vizsgált mutatók közül az egyik leggyengébb. Ez nagyrészt annak tudható be, hogy a high- és medium-tech iparágak foglalkoztatottainak aránya Budapesten, illetve az agglomerációban a tercier szektor túlsúlya miatt viszonylag alacsony. A térségek tolerancia szintjének becslésére az állampolgárság és a születési hely mutatóit használtuk. Ezek hatása valószínủleg gyengébb Magyarország kistérségeinek gazdasági fejlettségére, azonban szignifikáns pozitív kapcsolat mutatható ki közöttük.

A továbbiakban táblázatos formában mutatjuk be a 168 kistérségre alkalmazott és a 36 felsőfokú intézménnyel bíró kistérségre szủkített modelljeinket (6. táblázat). A magyarországi eredmények sok szempontból eltérnek mind a svéd, mind pedig az amerikai eredményektől.

Az elsô kutatási kérdésünk arra irányul, hogy a foglalkoztatottak képzettségi szintje vagy a foglalkozások jellege magyarázza-e jobban a régiók fejlettségét. Az eredményeink szerint a 168 kistérség esetén a humán tỏke és annak képzettségi színvonala jobban magyarázza a kistérségek közötti jövedelem-különbséget, mint a kreatív foglalkozások jelenléte (6. táblázat). Ugyanakkor a modell magasabb $\mathbf{R}^{2}$-tel, nagyobb magyarázóerỏvel bír a kreatív osztály esetén, mint a humán tỏke modellben. Ezen túlmenően a felsỏoktatási intézménnyel bíró 36 kistérségben a kreatív osztály jobban magyarázza a fejlettséget, mint a humán tőke. A svéd (MellanderFlorida 2007) és amerikai (Florida et al. 2008) vizsgálatokban egyértelmủen a kreatív osztály döntỏ szerepét mutatták ki, azonban az itt talált eredmények az átmeneti országok regionális fejlődésére utalhatnak. Ezek szerint a kreatív foglalkozások az egyetemi központokban magyarázzák eredményesen a regionális fejlődést, 
Lengyel Balázs - Ságvári Bence : Kreatív foglalkozások és regionális tudásbázis:

Fogalmak, folyamatok és területi összefüggések. - Tér és Társadalom 23. évf. 2009/4. 1-26. p.

ahol a foglalkoztatottak képzettségi szintje magasabb az átlagnál. Azonban ez nem igaz a teljes 168 kistérségre, ahol ellentétes trendek érvényesülnek, és a foglalkoztatottak képzettségi szintje gyakorol nagyobb hatást a jövedelem-különbségekre. Ez azt jelenti, hogy a kistérségek nagy részében magas azoknak a felsőfokú alkalmazottaknak a száma, akik nem tudnak elhelyezkedni felsőfokú végzettséget igénylö, kreatív foglalkozásokban.

\section{TÁBLÁZAT}

A 3 T modell változói közötti korrelációk mértéke (Correlation Values among the Model Indicators)

\begin{tabular}{|c|c|c|c|c|c|c|c|c|c|c|c|c|}
\hline & 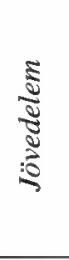 & 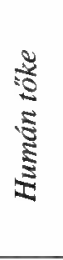 & 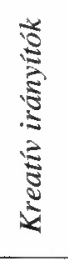 & 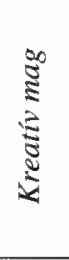 & 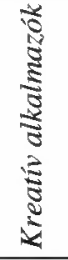 & 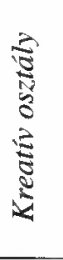 & 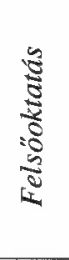 & 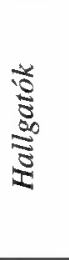 & 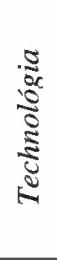 & 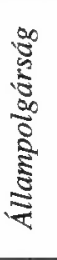 & 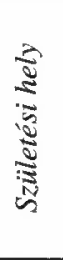 & 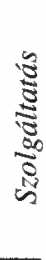 \\
\hline Jövedelem & 1 & & & & & & & & & & & \\
\hline Humán tóke &, 728 & 1 & & & & & & & & & & \\
\hline $\begin{array}{l}\text { Kreatív } \\
\text { irányítók }\end{array}$ &, 575 &, 781 & 1 & & & & & & & & & \\
\hline Kreatív mag &, 786 & ,951 &, 780 & 1 & & & & & & & & \\
\hline $\begin{array}{l}\text { Kreatív } \\
\text { alkalmazók }\end{array}$ &, 713 &, 826 &, 799 &, 824 & 1 & & & & & & & \\
\hline $\begin{array}{l}\text { Kreatív osz- } \\
\text { tály }\end{array}$ &, 748 &, 925 &, 880 & ,933 & ,962 & 1 & & & & & & \\
\hline $\begin{array}{l}\text { Egyetemi } \\
\text { oktatók }\end{array}$ &, 537 &, 794 &, 542 &, 827 &, 579 &, 708 & 1 & & & & & \\
\hline Hallgatók &, 443 &, 729 & ,462 &, 734 &, 537 & ,641 &, 912 & 1 & & & & \\
\hline Technológia &, 272 & & $\begin{array}{c}- \\
, 193\end{array}$ & & & & & & 1 & & & \\
\hline $\begin{array}{l}\text { Állampolgár- } \\
\text { ság }\end{array}$ &, 382 &, 350 &, 245 &, 425 &, 310 &, 351 &, 345 &, 274 & & 1 & & \\
\hline Születési hely &, 562 & ,466 &, 376 &, 562 & ,481 &, 509 &, 419 &, 322 & & 854 & 1 & \\
\hline Szolgáltatás &, 637 &, 729 &, 562 &, 740 & ,642 & ,707 &, 571 &, 544 & &, 346 & 448 & 1 \\
\hline
\end{tabular}

Megjegyzés: a korrelációs egyuitthatók 1\%-os szinten szignifikánsak, a *-al jelölt érték 5\%-os szinten szignifikáns.

Forrás: Saját számítás. 
Lengyel Balázs - Ságvári Bence : Kreatív foglalkozások és regionális tudásbázis:

Fogalmak, folyamatok és területi összefüggések. - Tér és Társadalom 23. évf. 2009/4. 1-26. p.

TÉT XXIII. évf. 2009 - 4

Kreatív foglalkozások és ... 19

\section{TÁBLÁZAT}

A $3 T$ útmodell eredményei a humán tỏke és a kreatív osztály adataival (3T Path-model Results for Human Capital and Creative Class)

\begin{tabular}{|c|c|c|c|c|c|c|c|}
\hline \multicolumn{4}{|c|}{ Humán tőke - 168 kistérség } & \multicolumn{4}{|c|}{ Kreatív osztály - 168 kistérség } \\
\hline & $\begin{array}{c}\text { Te- } \\
\text { hetség }\end{array}$ & $\begin{array}{c}\text { Tech- } \\
\text { nológia }\end{array}$ & $\begin{array}{l}\text { Regio- } \\
\text { nális } \\
\text { fejlödés }\end{array}$ & & $\begin{array}{c}\text { Te- } \\
\text { hetség }\end{array}$ & $\begin{array}{c}\text { Tech- } \\
\text { nológia }\end{array}$ & $\begin{array}{l}\text { Regio- } \\
\text { nális } \\
\text { fejlödés }\end{array}$ \\
\hline Tolerancia & ,066 &,- 110 &, $168^{* *}$ & Tolerancia & ,086 &,- 111 &, $159^{* *}$ \\
\hline Egyetem &, $465^{* *}$ & & $\begin{array}{l}(- \\
\left., 192^{* *}\right)\end{array}$ & Egyetem &, $355^{\text {*⿻* }}$ & & \\
\hline Kult.Szolg. &, $453^{* * 4}$ & ,069 & $\left(, 183^{* *}\right)$ & Kult.Szolg. &, $484^{* *}$ & 058 & $\left(, 191^{* *}\right)$ \\
\hline Tech- & &,- 106 & $\begin{array}{l}, 714^{* *} \\
, 363^{* *}\end{array}$ & $\begin{array}{l}\text { Tehetség } \\
\text { Tech- }\end{array}$ & & & ,652" \\
\hline $\begin{array}{l}\text { nológia } \\
\mathrm{R}^{2}\end{array}$ & ,714 & & & $\begin{array}{l}\text { nológia } \\
\mathrm{R}^{2}\end{array}$ & .727 & & \\
\hline \multicolumn{4}{|c|}{ Humán töke - 36 kistérség } & \multicolumn{4}{|c|}{ Kreativ osztály - 36 kistérség } \\
\hline & $\begin{array}{c}\text { Te- } \\
\text { hetség }\end{array}$ & $\begin{array}{c}\text { Tech- } \\
\text { nológia }\end{array}$ & $\begin{array}{c}\text { Regio- } \\
\text { nális } \\
\text { fejlödés }\end{array}$ & & $\begin{array}{c}\text { Te- } \\
\text { hetség }\end{array}$ & $\begin{array}{c}\text { Tech- } \\
\text { nológia }\end{array}$ & $\begin{array}{l}\text { Regio- } \\
\text { nális } \\
\text { fejlödés }\end{array}$ \\
\hline Tolerancia &, $338^{* *}$ &,- 063 & $261^{*}$ & Tolerancia &, $299^{* *}$ &,- 056 &, $273^{*}$ \\
\hline Egyetem &, $306^{* *}$ & & & Egyetem &, $302^{* *}$ & & \\
\hline Kult.Szolg. &, $476^{* *}$ &, 037 & & Kult.Szolg. &, $496^{* *}$ & 070 & \\
\hline Tehetség & &,- 255 &, $673^{* *}$ & Tehetség & &,- 310 &, $729^{* *}$ \\
\hline $\begin{array}{l}\text { Tech- } \\
\text { nológia }\end{array}$ & & &, $285^{* * *}$ & $\begin{array}{l}\text { Tech- } \\
\text { nológia }\end{array}$ & & &, $306^{* *}$ \\
\hline $\mathrm{R}^{2}$ & ,777 & & & $\mathbf{R}^{2}$ & 806 & & \\
\hline
\end{tabular}

Megjegyzés: ${ }^{* *} 1 \%$-os szignifikancia szintet, ${ }^{*} 5 \%$-os szignifikancia szintet jelöl.

Forrás: Saját számítás.

A vizsgálat második lépéseként a kreatív al-osztályaink regionális fejlettségre való hatását vizsgáltuk. Eredményeink szerint a kreatív irányítók csak kis mértékben, a kreatív alkalmazók közepes erősséggel magyarázzák a kistérségek fejlettségét, a kreatív mag jelenléte ugyanakkor rendkívül erős magyarázóerővel bír a régiók közötti jövedelem-különbségekben (7. táblázat). A 168 kistérségre és a 36 egyetemi kistérségre kiterjedỏ eredmények e tekintetben azonosak voltak.

A modell Technológia változója és az egyéb változók között nincs korrelációs kapcsolat, nem vagy alig magyarázható a Tolerancia, Tehetség vagy Kulturális Szolgáltatások változóival. Ezek ellenére az eddig felvázolt modellek mindegyikében a kistérségek technológiai színvonala mérsékelten erősnek bizonyult. Mindebből arra következtethetünk, hogy a magyar kistérségek technológiai színvonala fontos magyarázó erő az átmenet regionális fejlődésében, ugyanakkor a fejlett országokban alkalmazott módszer nem képes megragadni azokat a kủlsó tényezőket, amelyek a technológiai fejlődést itthon meghatározzák. Korábbi tanulmányok széles körủen rámutattak a külföldi beruházások és a külföldi tulajdonban lévô vállalatok szerepére a technológiai fejlődésben (Radosevic 2002; Inzelt 2003; Papanek 2006; 
Lengyel Balázs - Ságvári Bence : Kreatív foglalkozások és regionális tudásbázis:

Fogalmak, folyamatok és területi összefüggések. - Tér és Társadalom 23. évf. 2009/4. 1-26. p.

20 Lengyel Balázs - Ságvári Bence

TÉT XXIII. évf. 2009

4

Kállay-Lengyel I. 2008; Lengyel B.-Leydesdorff 2008). Sajnos a foglalkoztatási adatbázis korlátai miatt nem tudtuk a tulajdonviszonyokra vonatkozó mutatókat bevonni a vizsgálatba.

\section{TÁBLÁZAT}

Az út-modell eredményei a kreatív irányítók, mag és szakértök alosztályokkal (Result of Path Analyses for Creative Top, Creative Core, and Creative Professionals)

\begin{tabular}{|c|c|c|c|c|c|c|c|}
\hline \multicolumn{4}{|c|}{ Kreatív irányítók - 168 kistérség } & \multicolumn{4}{|c|}{ Kreatív irányítók - 36 kistérség } \\
\hline & $\begin{array}{l}\text { Tehet- } \\
\text { ség }\end{array}$ & $\begin{array}{c}\text { Tech- } \\
\text { nológia }\end{array}$ & $\begin{array}{c}\text { Regio- } \\
\text { nális } \\
\text { fejlö- } \\
\text { dés }\end{array}$ & & $\begin{array}{l}\text { Tehet- } \\
\text { ség }\end{array}$ & $\begin{array}{c}\text { Tech- } \\
\text { nológia }\end{array}$ & $\begin{array}{c}\text { Regio- } \\
\text { nális } \\
\text { fejlödés }\end{array}$ \\
\hline Tolerancia & 037 &,- 109 &, $205^{* *}$ & Tolerancia & 237 & ,084 & $386^{* *}$ \\
\hline Egyetem &, $218^{* *}$ & & & Egyetem &, 140 & & \\
\hline Kult.Szolg. & $430^{* *}$ &, 118 & $\left(, 342^{* *}\right)$ & Kult.Szolg. &, $384^{* *}$ &, 021 & $\left(, 368^{* *}\right)$ \\
\hline Tehetség & &,$- 225^{*}$ &, $382^{* *}$ & Tehetség & &,- 275 &, $463^{* *}$ \\
\hline Technológia & & & $396^{* *}$ & Technológia & & &, $333^{* *}$ \\
\hline $\mathbf{R}^{2}$ &, 649 & & & $\mathrm{R}^{2}$ &, 806 & & \\
\hline \multicolumn{4}{|c|}{ Kreatív mag - 168 kistérség } & \multicolumn{4}{|c|}{ Kreatív mag - 36 kistérség } \\
\hline & $\begin{array}{l}\text { Tehet- } \\
\text { ség }\end{array}$ & $\begin{array}{l}\text { Tech- } \\
\text { nológia }\end{array}$ & $\begin{array}{l}\text { Regio- } \\
\text { nális } \\
\text { fejlö- } \\
\text { dés }\end{array}$ & & $\begin{array}{l}\text { Tehet- } \\
\text { ség }\end{array}$ & $\begin{array}{l}\text { Tech- } \\
\text { nológia }\end{array}$ & $\begin{array}{c}\text { Regio- } \\
\text { nális } \\
\text { fejlódés }\end{array}$ \\
\hline Tolerancia &, $148^{* * *}$ &,- 121 &, 081 & Tolerancia &, $432^{* *}$ &,- 062 & 103 \\
\hline Egyetem &, $452^{* *}$ & & $\left(-, 262^{* *}\right)$ & Egyetem & $295^{* *}$ & & $\left(-238^{*}\right)$ \\
\hline Kult.Szolg. & $443^{* *}$ &, 012 & $\left(, 116^{*}\right)$ & Kult.Szolg. &, $417^{* *}$ &, 000 & \\
\hline Tehetség & &, 022 &, $883^{* *}$ & Tehetség & &,- 201 &, $891^{* *}$ \\
\hline Technológia & & &, $333^{* *}$ & Technológia & & &, $281^{* *}$ \\
\hline &, 774 & & & &, 828 & & \\
\hline \multicolumn{4}{|c|}{ Kreatív szakértők - 168 kistérség } & \multicolumn{4}{|c|}{ Kreativ szakértók - 36 kistérség } \\
\hline & $\begin{array}{l}\text { Tehet- } \\
\text { ség }\end{array}$ & $\begin{array}{c}\text { Tech- } \\
\text { nológia }\end{array}$ & $\begin{array}{l}\text { Regio- } \\
\text { nális } \\
\text { fejlö- } \\
\text { dés }\end{array}$ & & $\begin{array}{l}\text { Tehet- } \\
\text { ség }\end{array}$ & $\begin{array}{c}\text { Tech- } \\
\text { nológia }\end{array}$ & $\begin{array}{c}\text { Regio- } \\
\text { nális } \\
\text { fejlödés }\end{array}$ \\
\hline Tolerancia & ,075 &,- 118 &, $175^{* *}$ & Tolerancia & 187 &,- 112 & $392^{* *}$ \\
\hline Egyetem & $257^{* *}$ & & & Egyetem &, $280^{*}$ & & \\
\hline Kult.Szolg. & $476^{* *}$ &, 019 & $\left(, 270^{* *}\right)$ & Kult.Szolg. &, $577^{* *}$ &, 028 & \\
\hline Tehetség & &, 006 &, $498^{* *}$ & Tehetség & &,- 195 &, $508^{* *}$ \\
\hline Technológia & & &, $337^{* *}$ & Technológia & & & $273^{* *}$ \\
\hline $\mathbf{R}^{2}$ & 690 & & & $\mathbf{R}^{2}$ & ,750 & & \\
\hline
\end{tabular}

Megjegyzés: ${ }^{* *} 1 \%$-os szignifikancia szintet, ${ }^{*} 5 \%$-os szignifikancia szintet jelöl.

Forrás: Saját számítás.

A Tolerancia mutató a külföldön született foglalkoztatottak aránya a kistérségben, tehát leginkább a kistérségekbe irányuló nemzetközi mobilitást méri. Természetesen ez a mutató nagyon nagymértékben függ a kistérségek foglalkoztatottainak létszámától. Ennek megfelelően a Tolerancia sztenderdizált koefficiensei jóval magasabbak az 
egyetemi kistérségekben, mint a teljes mintában (lásd 6., 7. és 8. táblázat). Ez különösen erỏsen nyilvánul meg a Tolerancia mutató regionális fejlettségre való hatásában, ugyanakkor a Tolerancia a kistérségek technológiai színvonalát nem magyarázza.

A Kulturális Szolgáltatások változó a kreatív munka regionális eloszlására még nagyobb hatással bír. Az útmodell módszertanából következően a Kulturális Szolgáltatások néhány alkalommal közvetlen hatásúnak bizonyultak a regionális jövedelemkülönbségekre. Ezeket a hatásokat zárójelben jeleztük az eredmények között, ugyanis nem várhatunk közvetlen kapcsolatot. Sokkal inkább veti fel ez a jelenség a kauzalitás problémáját, hiszen inkább ellentétes a hatás, azaz a lakosság magasabb jövedelme miatt várható a szolgáltatások sokszínúségének kialakulása.

Az egyetemeknek a kreatív osztály regionális eloszlását közvetlenül és azon keresztül a fejlettséget közvetetten magyarázó szerepe meglehetősen csekély. Nem feltételezett közvetlen hatást a regionális fejlettségre több esetben is találtunk, azonban ez a hatás mindig negatívnak bizonyult. Azaz, minél nagyobb a nappali tagozatos hallgatók aránya a foglalkoztatottakhoz képest, annál alacsonyabb regionális jövedelemre számíthatunk. Ennek a magyarázata az lehet, hogy a legnagyobb egyetemeink az ország kevésbé fejlett régióiban találhatók (Lengyel B.-Leydesdorff 2008; Lengyel I. 2009). Ennek megfelelően az Egyetem változó jóval nagyobb hatással van a Tehetség képzettségi oldalú, humán tőke változójára, mint a kreatív foglalkozásokra.

\section{A foglalkozások és egyetemi képzések tudásbázisa a $3 T$ modellben}

Az egyetemi képzések és foglalkozások tudásbázisai az innovációs rendszerek két külön alrendszerének részei, amelyeket itt igyekszünk közös nevezőre hozni. Az előző vizsgálatok által feltárt összefüggések további részletezése érdekében a hazai felsőoktatási intézményeken nappali képzésben résztvevők számát analitikus, szintetikus és szimbolikus összetevőkre bontottuk. A képzési adatok felbontásakor jelen esetben a foglalkozási tudásbázis analógiáját használtuk, azaz az analitikus szakok közé soroltuk a természettudományi, múszaki tudományi- és élettudományi képzéseket; a szintetikus szakok a társadalomtudományi képzéseket ölelik fel; a szimbolikus tudásbázis gyarapítása pedig a bölcsészettudományi-, múvészeti- és hittudományi képzéseken alapul.

A módszerünk és kategóriáink elsősorban azt a célt szolgálják, hogy egységesen tudjuk kezelni a képzési és foglalkozási szerkezetet. Ezért itt lemondunk az analitikus-szintetikus tudásbázis összehasonlításának eredeti céljáról, nem tudjuk azokat megkülönböztetni az explicit-hallgatólagos tudás kettőse szerint. Nem tudjuk tehát megmondani, hogy az inkább explicit tudásátadásra épülö, így globális szinten múvelt természettudományi vagy a jobban gyakorlat-orientált, ezáltal helyhez kötődő múszaki- és élettudományi képzések felelősek-e a lokális gazdasági fejlődésért. Ehelyett a kérdésfeltevésünk arra vonatkozik, hogy milyen tényezők határozzák meg a kreatív munkavállalók lakóhely-választási döntéseit a szerint, hogy tudásukat földrajzi helytől függetlenül vagy ahhoz kötődve képesek kamatoztatni. Azt feltételezzük, hogy az analitikus foglalkoztatottak a legmobilabbak, tudásukat akár külföldön 
Lengyel Balázs - Ságvári Bence : Kreatív foglalkozások és regionális tudásbázis:

Fogalmak, folyamatok és területi összefüggések. - Tér és Társadalom 23. évf. 2009/4. 1-26. p.

is könnyen tudják használni. Ezzel szemben a szintetikus alkalmazottak tudása a helyi társadalmi, gazdasági rendszerre specializált. Ebből adódóan az analitikus egyetemi képzések és az analitikus foglalkozások között alacsonyabb kapcsolatot feltételezünk, mint a szintetikus képzések és szintetikus foglalkozások között. Az út-modell harmadik lépéseként a fenti gondolatmenetet teszteljük (8. táblázat).

\section{TÁBLÁZAT}

Útmodell eredmények az analitikus-, szintetikus- és szimbolikus tudásbazis alapján (Path-model Results of Analytic, Synthetic and Symbolic Knowledge Bases)

\begin{tabular}{|c|c|c|c|c|c|c|c|}
\hline \multicolumn{4}{|c|}{ Analitikus tudásbázis - 168 kistérség } & \multicolumn{4}{|c|}{ Analitikus tudásbázis - 36 kistérség } \\
\hline & $\begin{array}{c}\text { Te- } \\
\text { hetség }\end{array}$ & $\begin{array}{c}\text { Tech- } \\
\text { nológia }\end{array}$ & $\begin{array}{c}\text { Re- } \\
\text { gionális } \\
\text { fejlödés }\end{array}$ & & $\begin{array}{c}\text { Te- } \\
\text { hetség }\end{array}$ & $\begin{array}{c}\text { Tech- } \\
\text { nológia }\end{array}$ & $\begin{array}{c}\text { Re- } \\
\text { gionális } \\
\text { fejlódés }\end{array}$ \\
\hline Tolerancia &, $143^{* * *}$ &,- 149 &, $096^{* *}$ & Tolerancia & $477^{* *}$ &,- 288 & ,086 \\
\hline Egyetem &, $334^{* *}$ & & $\left(-, 163^{* *}\right)$ & Egyetem &, $243^{*}$ & & $\left(-, 217^{*}\right)$ \\
\hline Kult.Szolg. &, $536^{* *}$ &,- 103 & & Kult.Szolg. &, $417^{* *}$ &,- 189 & \\
\hline Tehetség & & 207 &, $790^{* *}$ & Tehetség & &, 183 &, $827^{* *}$ \\
\hline $\begin{array}{l}\text { Techn. } \\
\mathrm{R}^{2}\end{array}$ &, 764 & &, $279^{* *}$ & $\begin{array}{l}\text { Techn. } \\
\mathrm{R}^{2}\end{array}$ &, 818 & &, $203^{*}$ \\
\hline \multicolumn{4}{|c|}{ Szintetikus tudásbázis - 168 kistérség } & \multicolumn{4}{|c|}{ Szintetikus tudásbázis - 36 kistérség } \\
\hline & $\begin{array}{c}\text { Te- } \\
\text { hetség }\end{array}$ & $\begin{array}{c}\text { Tech- } \\
\text { nológia }\end{array}$ & $\begin{array}{c}\text { Re- } \\
\text { gionális } \\
\text { fejlödés }\end{array}$ & & $\begin{array}{c}\text { Te- } \\
\text { hetség }\end{array}$ & $\begin{array}{c}\text { Tech- } \\
\text { nológia }\end{array}$ & $\begin{array}{c}\text { Re- } \\
\text { gionális } \\
\text { fejlödés }\end{array}$ \\
\hline Tolerancia &, $177^{* *}$ &,- 142 &, 086 & Tolerancia &, $489^{* *}$ &,- 176 &, 186 \\
\hline Egyetem &, $305^{* *}$ & & $\left(-, 109^{* *}\right)$ & Egyetem &, 096 & & \\
\hline Kult.Szolg. &, $533^{* *}$ &,- 070 & & Kult.Szolg. &, $510^{* *}$ &,- 140 & \\
\hline Tehetség & &, 101 &, $739^{* *}$ & Tehetség & &,- 096 &, $621^{* * *}$ \\
\hline Techn. & & &, $307^{* * *}$ & Techn. & & &, $252^{* *}$ \\
\hline $\mathbf{R}^{2}$ &, 733 & & & $\mathrm{R}^{2}$ & .758 & & \\
\hline \multicolumn{4}{|c|}{ Szimbolikus tudásbázis - 168 kistérség } & \multicolumn{4}{|c|}{ Szimbolikus tudásbázis - 36 kistérség } \\
\hline & $\begin{array}{c}\text { Te- } \\
\text { hetség }\end{array}$ & $\begin{array}{c}\text { Tech- } \\
\text { nológia }\end{array}$ & $\begin{array}{l}\quad \text { Re- } \\
\text { gionális } \\
\text { fejlódés }\end{array}$ & & $\begin{array}{c}\text { Te- } \\
\text { hetség }\end{array}$ & $\begin{array}{c}\text { Tech- } \\
\text { nológia }\end{array}$ & $\begin{array}{c}\text { Re- } \\
\text { gionális } \\
\text { fejlödés }\end{array}$ \\
\hline Tolerancia &, $203^{* *}$ &,- 108 &, $120^{*}$ & Tolerancia &, $534^{* *}$ &,- 018 &, 166 \\
\hline Egyetem &, $309^{* *}$ & & & Egyetem & ,094 & & \\
\hline Kult.Szolg. &, $390^{* *}$ &, 027 & $\left(, 355^{* *}\right)$ & Kult.Szolg. &, $391^{* *}$ &,- 003 & $\left(, 307^{* *}\right)$ \\
\hline Tehetség & &,- 054 & $485^{* *}$ & Tehetség & &,- 313 &, $646^{* *}$ \\
\hline $\begin{array}{l}\text { Techn. } \\
\mathbf{R}^{2}\end{array}$ & ,672 & &, $349^{*}$ & $\begin{array}{l}\text { Techn. } \\
\mathrm{R}^{2}\end{array}$ &, 812 & &, $308^{* *}$ \\
\hline
\end{tabular}

Megjegyzés: "* $1 \%$-os szignifikancia szintet, ${ }^{*} 5 \%$-os szignifikancia szintet jelöl.

Forrás: Saját számítás.

Az előzó eredményekkel összhangban egyik egyetemi specializáció esetében sem találtunk közvetlen hatást a regionális fejlettségre. Ezen kívuil a Technológia indikátor csak kismértékben magyarázza a jövedelemkülönbségeket. A kreatív foglalkozások 
valószínüleg nem a high-tech és medium-tech szektorokon keresztül fejtik ki hatásukat a jövedelem-különbségekre, sokkal inkább a szolgáltatásokban koncentrálódnak.

A regionális jövedelemszintet legnagyobb mértékben az analitikus foglalkozások tudásbázisa magyarázza, melyet erősségében majdnem utolér a szintetikus tudásbázis, ettől viszont a szimbolikus már elmarad. Az egyetemeknek a foglalkozási szerkezetre való lokális hatása mérsékelt mindhárom tudásbázis esetében. Azonban várakozásainkkal ellentétben éppen a tudását tekintve legmobilabb analitikus foglalkozások körében a legerősebb a kapcsolat a helyi egyetemi képzéssel. A szintetikus és szimbolikus képzések esetében még gyengébb a kapcsolat, ami valószínúleg azt mutatja, hogy ezek a foglalkozások a nagyvárosi és egyetemi központokban koncentrálódnak. A 36 egyetemi kistérség eredményei szintén ezt a következtetést támasztják alá: a hatás szignifikáns maradt az analitikus tudásbázis esetében, ugyanakkor az egyetemi központokban a szintetikus és szimbolikus képzés aránya nem magyarázza a megfelelő foglalkozások arányát.

\section{Konklúzió és további kutatási irányok}

A tanulmányban bemutattuk a regionális innovációs rendszerek tudásbázisának foglalkozási oldalú megközelítését és az erre irányuló hazai kutatásunkat. Nemzetközi viszonylatban is új kísérletnek tekinthető a foglalkozási adatok teljes körú értelmezése a foglalkozások regionális innovációs rendszerek tudásbázisára való hatását tekintve. Szintén újszerü, ahogy az egyetemi képzések és a foglalkozások tudásbázisának területi összefüggéseit kimutattuk.

Az 1995 utáni átmenetben a tudásbázisok eltérő növekedése volt tapasztalható a hazai megyékben. Míg az analitikus tudásbázis (természettudósok, orvosok és mérnökök) teruileti megoszlásának alakulása a kiegyenlítődés irányába mutat, addig a szintetikus tudásbázis (közgazdászok, jogászok) egyre inkább a fövárosban koncentrálódik. A regionális fejlettséget a felsőfokú végzettséggel rendelkező foglalkoztatottak erősebben magyarázzák, mint a kreatív foglalkozásokban dolgozók. Ez az eredményünk ellentmond a szakirodalom tapasztalatainak (Mellander-Florida 2007; Florida et al. 2008), ami arra utal, hogy a nemzeti innovációs rendszerek valószínủleg különböznek e tekintetben, nem vonhatók le általános érvényú megállapítások a kreatív osztály lokális szerepét illetően. A tudásbázisok regionális fejlettségét a kreatív mag magyarázza a legerősebben, ezt a kreatív alkalmazottak követik, a kreatív vezetők viszont csekélyebb magyarázó erővel bírnak. Azt a következtetést vonjuk le ebből, hogy a kreatív mag alkalmazottai nagyobb hatással vannak a regionális növekedésre és fejlódésre, mint a kreatív vezetők.

Az egyetemek hatása a lokális tudásbázisra az analitikus képzések és foglalkozások kapcsolatában erősebb, mint a szintetikus összehasonlítás párnál. Ez az eredményünk szintén ellentmond a szakirodalom tapasztalatainak. Ezek szerint azt várnánk, hogy a szintetikus tudásbázis a hallgatólagos tudáselemek nagyobb aránya miatt jobban helyhez kötődik, mint az explicit módon könnyebben elmondható 
tudásra épülő analitikus tudásbázis. Mivel hasonló vizsgálatot nem végeztek eddig, nemzetközi összehasonlításra itt nem tudunk támaszkodni. Azonban élünk azzal a megállapítással, hogy Magyarországon a globális nyitás és az átmenet egyidejü kiteljesedése terén valószínúleg az EU15-ök országaitól eltérô területi folyamatok mentek végbe. A gazdasági tevékenység koncentrálódásának következtében a szintetikus foglalkozások egyre eröteljesebben összpontosulnak a fövárosban, ami azt jelenti, hogy a vidéki egyetemek szintetikus képzései csak kis hatással vannak a lokális szintetikus tudásbázisra.

Számos további problémával szembesülünk azonban, amelyek a módszerhez és a modellhez kapcsolódnak, s melyeket a jövőben igyekszünk megoldani. Adatfelvételi probléma például, hogy a bejelentett lakcím és a tényleges tartózkodási hely gyakran eltér, föleg a fiatal munkavállalók esetében.

A saját kategóriáinkból adódó definíciós problémák szintén további elméleti munkát igényelnek. Tovább kell pontosítani a kreatív vezetők, kreatív mag és a kreatív alkalmazók munkavégzése közti különbségeket. Például nem feltétlenül igaz, hogy aki egyetemet végez, az a nagyobb önállósággal bíró munkakörökben fog dolgozni, mint aki föiskolai szintủ végzettséggel rendelkezik. Sót, gyakran elöfordul, hogy egyetemi diplomával rendelkezők azonos tudásbázisban helyezkednek el a kreatív alkalmazók körén belül (lásd középiskolai tanárok), vagy a bölcsész diplomával rendelkezők töredéke tud csak elhelyezkedni szakmájában. Szintén további problémát okoz a felsőoktatási intézmények közötti különbségek megragadása a tudásbázis-teremtést illetỏen: itt például egy osztályba kerültek a müszaki föiskolák és a magasabb színvonalú egyetemek.

További elméleti problémáink közé tartozik az is, hogy az egyetemek humán tôkében érvényesülő hatásai nem feltétlenül lokálisak. Fóleg igaz ez hazánkra, ahol a városok közötti távolságok kicsik, és egy központ vonzza magához az egyetemi végzetteket. Véleményünk szerint Magyarország esetében érdekes kérdés például az, hogy a vidéki egyetemeken végzők milyen kondíciókkal tudnak vidéken maradni, mi vezérli más térségekben, illetve a fővárosban való letelepedésüket.

Szintén további kutatásokat igényelnek az FDI által vezérelt kreatív munkavégzés és a regionális növekedés lokális összefüggései (Inzelt 2008). Korábbi munkáinkban megmutattuk, hogy a nyugati megyék innovációs rendszerei a külföldi tulajdonú vállalatok által szervezettek, míg a keleti megyékben meghatározóak maradtak az állami struktúrák (Lengyel B.-Leydesdorff 2008). Ehhez hasonlóan láthattuk, hogy az állami intézményeknél és a külföldi tulajdonú vállalatokban foglalkoztatottak aránya a kreatív foglalkoztatottakon belül nagyon eltérö területi képet mutatott 2005-ben, az ország két részre osztható e tekintetben (Ságvári-Lengyel B. 2008). Az állami alkalmazottak aránya az ország keleti (fóleg északkeleti) és déli megyéiben átlagon felüli, a külföldi tulajdonban lévő cégeknél dolgozó kreatívok az átlagosnál jóval nagyobb arányban vannak jelen az északnyugati megyékben. E téma kifejtése azonban már egy következỏ tanulmány feladata. 


\section{Irodalom}

Asheim, B.T.-Coenen, L. (2006) Tudásbázisok és regionális innovációs rendszerek: skandináviai klaszterek összehasonlítása. - Információs Társadalom. 3. 114-141. o.

Asheim, B.T.-Gertler, M.S (2005) The Geography of Innovation. Regional Innovation Systems. Faberger, J.-Mowery, D.C.-Nelson, R.R. (eds.) The Oxford Handbook of Innovation. Oxford University Press, Oxford. 291-317. o.

Asheim, B.T.-Isaksen, A. (2002) Regional innovation systems: the integration of local „sticky” and global „ubiquitous" knowledge. - Journal of Technology Transfer. 27. 77-86. o.

Cooke, P.-Schwartz, D. (2007) Creative regions: technology, culture and knowledge entrepreneurship. Routledge, London.

Florida, R. (2002a) The Rise of the Creative Class. Basic Books, New York.

Florida, R. (2002b) The Economic Geography of Talent. - Annals of the Association of American Geographers. 92. 743-755, o.

Florida, R.-Tinagli, I. (2004) Europe in the Creative Age. Demos, London.

Florida, R.--Mellander, Ch.-Stolarick, K. (2008) Inside the black box of regional development: human capital, the creative class and tolerance. - Joumal of Economic Geography. 8. 615-649. o.

Glaeser, E.-Kallal, H.D.-Scheinkman, J.D.-Shleifer, A. (1992) Growth in cities. - Journal of Political Economy. 100. 1126-1152. o.

Inzelt, A. (2003) Foreign involvement in acquiring and producing new knowledge: the case of Hungary. - Cantwell, J.-Molero, J. (eds.) Multinational Enterprises, Innovative Strategies and Systems of Innovation. Edward Elgar, Cheltenham-Northampton. 234-268. o.

Inzelt A. (2008) The inflow of highly skilled workers into Hungary: a by-product of FDI. - Journal of Technology Transfer. 33. 422-438. o.

Jacobs, J. (1969) The Economy of Cities. Random House, New York.

Kállay, L.-Lengyel, I. (2008) The internationalisation of Hungarian SMEs. - Dana, L.-Han, M.-Ratten, V.Welpe I. (eds.) A Theory of Internationalisation for European Entrepreneurship. Edward Elgar, Cheltenham-Northampton. 277-295. o.

Lengyel B. (2004) A tudásteremtés lokalitása: hallgatólagos tudás és helyi tudástranszfer. - Tér és Társadalom. 2. 51-71. o.

Lengyel B.-Leydesdorff, L. (2008) A magyar gazdaság tudásalapú szerveződésének mérése: az innovációs rendszerek szinergiáinak térbelisége. - Közgazdasági Szemle. Június. 522-527. o.

Lengyel I. (2003) Verseny és területi fejlödés: térségek versenyképessége Magyarországon. JATEPress, Szeged.

Lengyel, I. (2009) Knowledge based local economic development for enhancing competitiveness in lagging areas of Europe: The case of the University of Szeged. - Varga A. (ed.) Universities, Knowledge Transfer and Regional Development: Geography, Entrepreneurship and Policy. Edward Elgar, CheltenhamNorthampton. 322-349. o.

Lengyel I.-Rechnitzer J. (2004) Regionális gazdaságtan. Dialóg Campus, Budapest-Pécs.

Mellander, Ch.-Florida, R. (2007) The Creative Class or Human Capital? Explaining regional development in Sweden. CESIS Electronic Working Paper Series, No. 79.

Papanek G. (2006) Tudásáramlás, jogbiztonság, együttmüködés: a magyar gazdaság fejlödésének láthatatlan forrásai. Aula, Budapest.

Radosevic, S. (2002) Regional Innovation Systems in Central and Eastern Europe: Determinants, Organizers and Alignments. - Journal of Technology Transfer. 27. 87-96. o.

Rechnitzer J.-Csizmadia Z.-Grosz A. (2004) A magyar városhálózat tudásalapú megújító képessége az. ezredfordulón. - Tér és Társadalom. 2. 117-156. o.

Rimler J. (2000) Munkák és munkásaik. Kreatív irányú eltolódások a magyar munkapiacon. Közgazdasági Szemle. 10. 832-842. o.

Ságvári B.-Dessewffy T. (2006) A kreatív gazdaságról, Magyarország és Európa a kreatí korban. Demos Hungary, Budapest.

Ságvári, B.-Lengyel, B. (2008) Kreatív atlasz: a magyarországi kreatív munkaeró területi és idóbeli változásáról. Demos Hungary, Budapest.

Schumpeter, J. (1961) The Theory of Economic Development. Oxford University Press, Oxford-New York.

Scott, A.J. (2007) Capitalism and urbanization in a new key? The cognitive-cultural dimension. - Social Forces. 85. 1465-1482. o.

Varga A. (2004) Az egyetemi kutatások regionális gazdasági hatásai a nemzetközi szakirodalom tükrében. Közgazdasági Szemle. Március. 259-275. o. 
Lengyel Balázs - Ságvári Bence : Kreatív foglalkozások és regionális tudásbázis:

Fogalmak, folyamatok és területi összefüggések. - Tér és Társadalom 23. évf. 2009/4. 1-26. p.

\section{CREATIVE OCCUPATIONS AND REGIONAL KNOWLEDGE BASE: CONCEPTS, TRENDS AND TERRITORIAL CORRESPONDENCES}

\section{BALÁZS LENGYEL - BENCE SÁGVÁRI}

In this paper we introduce the occupational aspects on creative work into the Hungarian literature. We give an overview on the evolution of spatial knowledge bases, using own categories, during the 1996-2005 period. After that following the 3T model developed on Swedish regions, we explain the regional development differences with sub-regional indicators on creative work, technology level of the economy, level of tolerance, volume of higher education, and diversity of amenities. We develop the model further, analytic-, synthetic-, and symbolic knowledge bases are distinguished in the new version, the local correspondences among university and occupational knowledge bases are analyzed according to these categories.

Our results suggest that creative core explains regional development with a very high degree. Also creative professionals have a strong effect on regional development, while the influence of creative leaders is weaker. The graduated workforce explains regional development better in Hungary than the creative workforce, which contradicts to international experiences. This finding suggests that due to the transition state of the Hungarian economy graduated labour does not always occupied in creative jobs. We also found a paradox to the literature on knowledge bases: the effect of university education is stronger in the analytic knowledge base than in synthetic knowledge base. During the opening of the Hungarian economy the capital and its agglomeration became the gate to external markets, and the gate for foreign firms to the local market. This process attracted the economic-, legal-, and social knowledge to the capital. 